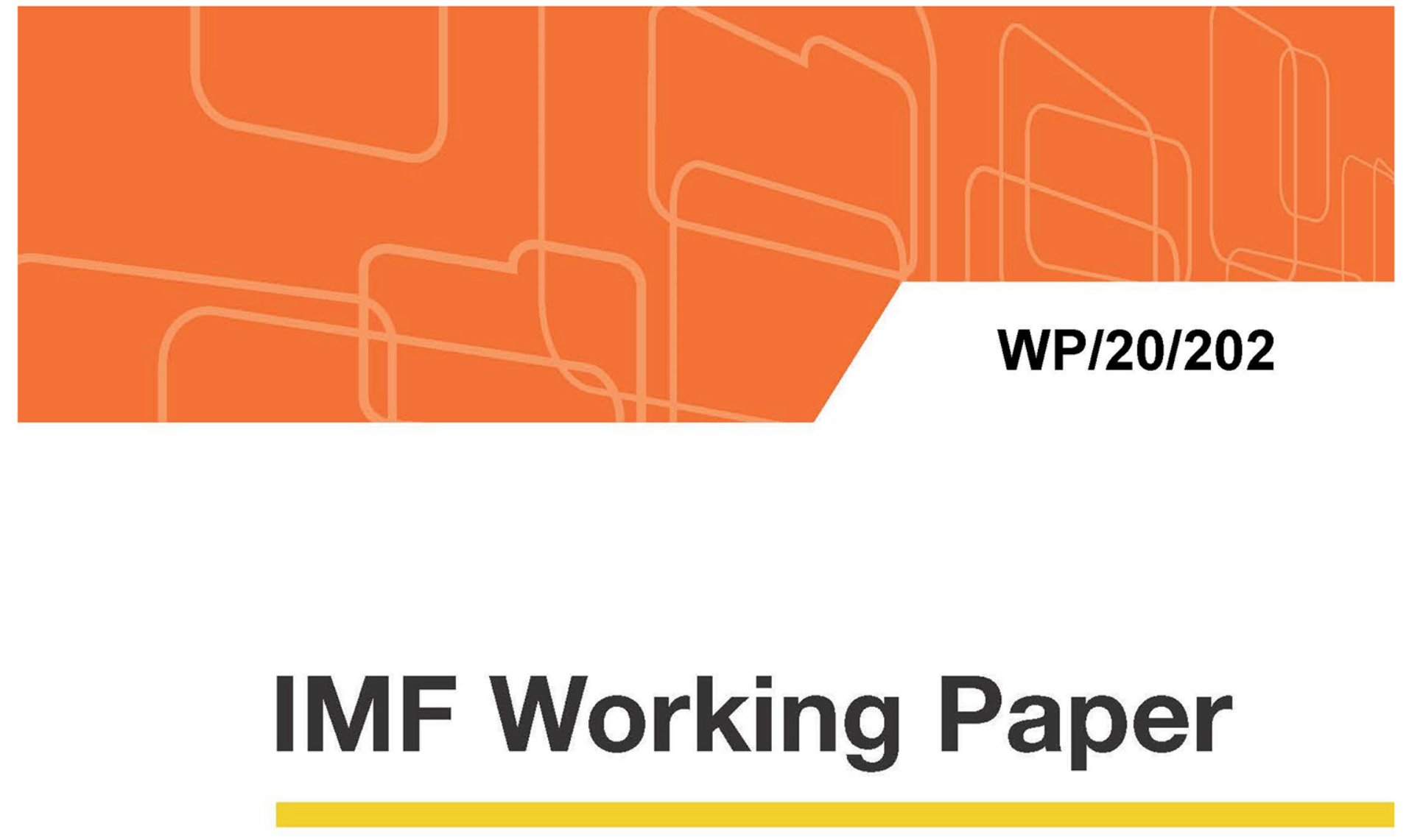

\title{
A Simple Macrofiscal Model for Policy Analysis: An Application to Cambodia
}

by Dániel Baksa, Aleš Buliř, and Dyna Heng

IMF Working Papers describe research in progress by the author(s) and are published to elicit comments and to encourage debate. The views expressed in IMF Working Papers are those of the author(s) and do not necessarily represent the views of the IMF, its Executive Board, or IMF management. 


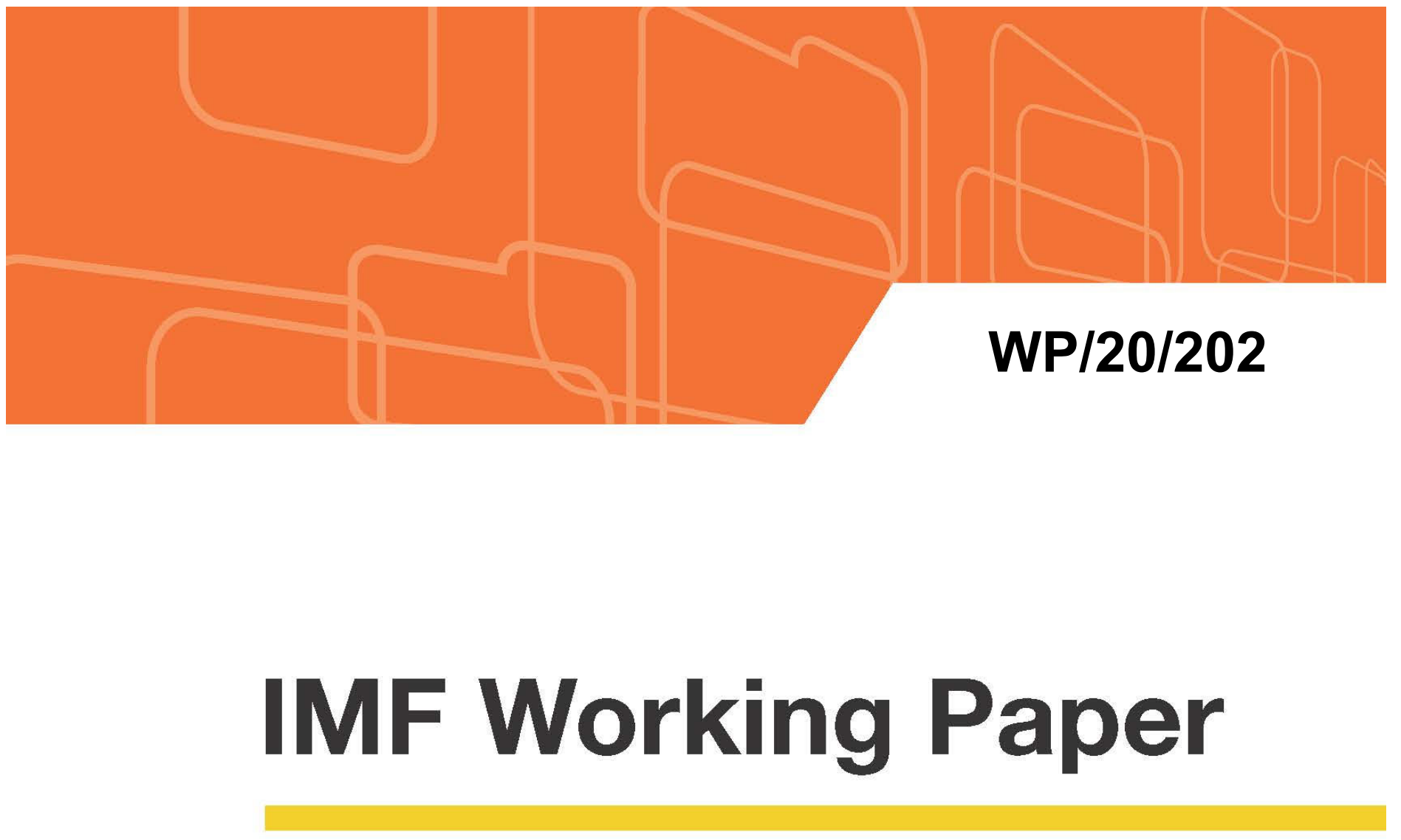

\section{A Simple Macrofiscal Model for Policy Analysis: An Application to Cambodia}

by Dániel Baksa, Aleš Buliřr, and Dyna Heng

IMF Working Papers describe research in progress by the author(s) and are published to elicit comments and to encourage debate. The views expressed in IMF Working Papers are those of the author(s) and do not necessarily represent the views of the IMF, its Executive Board, or IMF management.

$$
\text { I N T E R N A T I O N A L M O N E T A R Y F U N D }
$$




\title{
IMF Working Paper
}

Institute of Capacity Development

\section{A Simple Macrofiscal Model for Policy Analysis: An Application to Cambodia ${ }^{1}$}

Prepared by Dániel Baksa, Aleš Bulíř, and Dyna Heng

Authorized for distribution by Norbert Funke

September 2020

IMF Working Papers describe research in progress by the author(s) and are published to elicit comments and to encourage debate. The views expressed in IMF Working Papers are those of the author(s) and do not necessarily represent the views of the IMF, its Executive Board, or IMF management.

\begin{abstract}
The paper describes a semistructural macrofiscal approach to simulating and forecasting macroeconomic policies. Our canonical model is adapted to Cambodia and we demonstrate its application with an illustrative scenario of macroeconomic effects of the Covid-19 pandemic. Complemented with near-term forecasting tools and expert judgment, the dynamics of the model helps to inform policymakers about medium-term transmission channels and thus guide policy advice.
\end{abstract}

JEL Classification Numbers: E32, E52, E58, E62, F47

Keywords: Fiscal Policy, Cambodia, Fiscal Multiplier

Author's E-Mail Address: dbaksa2@,imf.org, abulir@imf.org, dheng@,imf.org

\footnotetext{
${ }^{1}$ This paper greatly benefited from discussions with staff of Cambodia's Ministry of Economy and Finance, the National Bank of Cambodia, and the IMF country team. We are grateful for comments from Ritu Basu, Andy Berg, Mariya Brussevich, Norbert Funke, and Alasdair Scott and from participants at several IMF seminars. The views expressed in this paper are those of the authors and not necessarily those of the Cambodian authorities, the International Monetary Fund, or its Executive Board.
} 


\section{Contents}

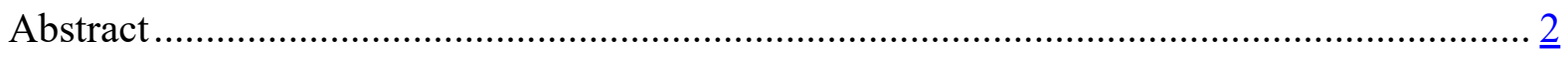

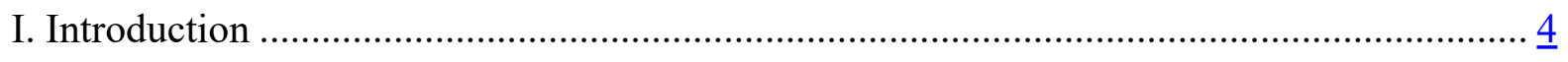

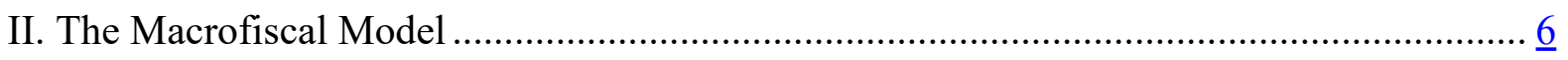

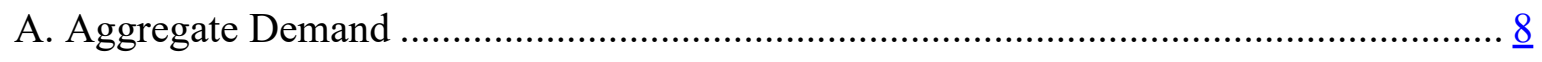

B. Aggregate Supply ........................................................................................ 10

C. The Exchange Rate, Uncovered Interest Rate Parity, and the Policy Reaction Function

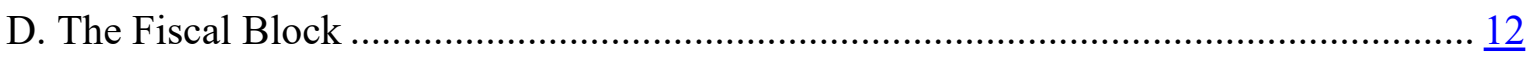

III. Recent economic Developments in Cambodia and CAMFI Calibration........................... 14

A. Recent Economic Developments ……………………….................................... 14

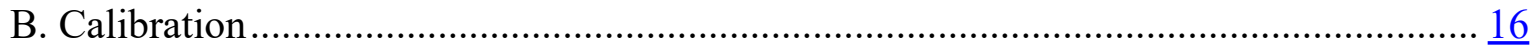

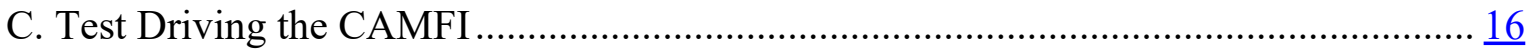

Impulse Responses..................................................................................... 17

Multivariate Filter Results .............................................................................. 20

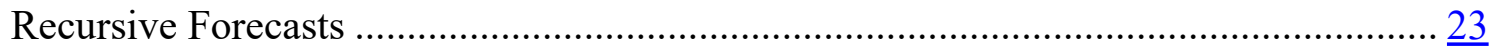

IV. A Policy-Relevant Exercise .............................................................................. 24

A. Scenario Building and Assumptions ..................................................................... 24

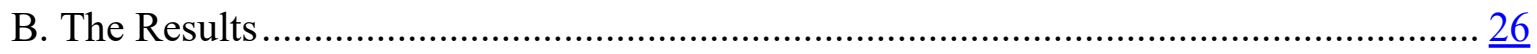

V. Caveats and Potential Extensions …………………................................................ 27

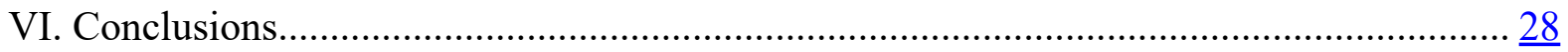

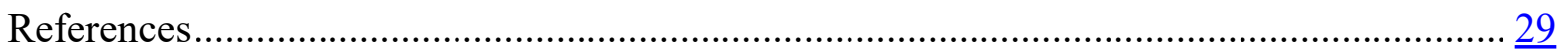

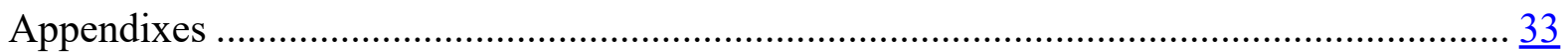

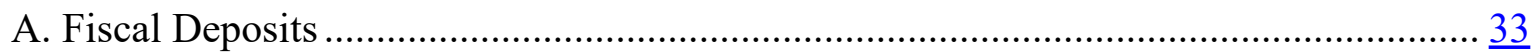

B. The Fiscal Multiplier Estimates for Cambodia …………………………………….... $\underline{34}$

C. The CAMFI Model Codes..................................................................................... 


\section{"Everything should be made as simple as possible, but no simpler." A quote attributed to Albert Einstein}

\section{INTRODUCTION}

For the past 30 years, economists have been building simple policy-relevant models, typically with either a monetary or a fiscal transmission mechanism; rarely do these models give equal attention to both. Most policy applications have been adopted by central banks rather than ministries of finance. In contrast, we build a parsimonious semistructural model that can be used to simulate and forecast the effects of both monetary and fiscal policies for all relevant monetary and exchange rate arrangements. Compared to more detailed IMF financial programming (FP) built around many variables and identities, this model uses fewer variables, but they are bound together in a way that has been tested both theoretically and empirically. We have adapted the basic approach for use in Cambodia and present a scenario of possible macroeconomic effects of the Covid-19 pandemic there.

We augment the standard New Keynesian monetary transmission channels for stylized fiscal interactions and debt dynamics; for the former, our model consists of an aggregate demand (IS) curve; a price-setting (Phillips) curve; an uncovered interest rate parity (UIP) relationship; and a monetary policy reaction function that reflects the given monetary and exchange rate arrangement. ${ }^{2}$ These building blocks embody the principle that the fundamental role of monetary policy is to anchor inflation and inflation expectations. To capture the role of the fiscal authority, we add the fiscal balance, its financing, debt dynamics, and a fiscal policy reaction function. This structure is consistent with a view of the world where because nominal and real rigidities prevent instantaneous adjustment in prices and wages, in the short run aggregate demand determines output; expectations matter for inflation, output, and fiscal sustainability; and both monetary and fiscal policy are rule-based and predictable.

The model presented here could be a useful addition to the standard toolkit of teams who are tasked to analyze scenarios for macroeconomic policies and assess their impact. Developing and comparing such scenarios is time-consuming, particularly to ensure internal consistency when there is not a solid structure. A parsimonious model that can be scaled up could become a backbone of the standard analysis toolkit. The goal of this paper is to first define and then test such a minimalist approach.

To be widely applicable, a model must satisfy two conditions: (1) It must take into account generally accepted fiscal and monetary transmission channels, and (2) it should be parsimonious so that it is usable in countries with low-frequency data and without a tradition of model-based policy analysis. Indeed, our target audience is countries that have not had at their disposal sophisticated models to support macroeconomic decision making. We will present results of a current technical assistance project for Cambodia that uses such an approach.

\footnotetext{
${ }^{2}$ We build on the model by Kamenik and others (2013).
} 
Cambodia is a fast-growing, lower-middle-income, open economy. Because it is vulnerable to adverse external shocks, its policymakers seek to understand how such shocks are propagated, their medium- and long-term impacts on Cambodia's economy, and the likely effect of alternative domestic policy responses to these shocks. To date, two analytical streams have been pursued, each having both pros and cons.

(1) The Ministry of Economy and Finance (MEF) and National Bank of Cambodia (NBC) use IMF financial programming (FP) derived from an interconnected set of macroeconomic accounts: national income and product accounts, balance of payments, government finance statistics, and monetary accounts. FP has value because of its detail and use of a bottom-up approach and as a consistency check, especially when supplemented by other analytical tools. However, the detailed FP framework has limitations as a forecasting tool and as a guide to the conduct of macroeconomic policies and formulation of scenarios: much of the long-term, general equilibrium interaction between quantities and prices is generally ad hoc. (2) The NBC, the Bank of Korea (BOK), and Yonsei University have together developed a sophisticated dynamic stochastic general equilibrium (DSGE) model (BOK Knowledge Partnership Program with Cambodia, 2016). While it is on the frontier of current DSGE modeling practices, its complexity makes it difficult to update regularly for application to policy-relevant questions.

To find a middle ground between detailed data and frontier theoretical consistency and to serve as a tool for scenario analysis, we develop and calibrate a simple macrofiscal, semistructural model that captures stylized facts about Cambodia's economy. We call it the Cambodia Macrofiscal Model (CAMFI). The key benefit of our approach is that it strictly limits the number of macroeconomically relevant variables while retaining theoretical consistency. For the sake of parsimony, we drop sectors and variables that are less relevant to the specific analysis or that cannot be modeled easily for Cambodia. For example, in Cambodia the policy analysis focuses on domestic developments, but because the current account deficit (CAD) is financed entirely by sustainable foreign direct investment (FDI) inflows, there is not much benefit from modeling components of the trade or financial balance. Similarly, because the supply side in the semistructural models is largely exogenous, there is little to gain from modeling revenue and expenditure components-imposing revenue- and expenditure-specific multipliers would be superficial. Therefore, in our model the fiscal authority chooses a single policy variable: the cyclically-adjusted primary balance.

We recognize that by simplifying the external sector into a risk premium variable or aggregating all fiscal operations into the primary balance variable we are foregoing the possibility of a more granular analysis. Should the simulation tasks change, or different sectors and components gain prominence, the model would need to be either extended to such new factors or supplemented by satellite models. We remain mindful, however, of the cost of expansion - the comparative simplicity of this model allows much simpler data updates than traditional FP.

We calibrate the model, apply it to the Cambodian data, and then illustrate how it works in several applications: impulse response functions, a multivariate filtration to obtain important 
unobserved variables, testing the model's recursive forecasting capability, and designing an exercise to simulate the medium-term economic impact of Covid-19 shock. The CAMFI results conform with past empirical analyses of the Cambodian economy and stylized facts, and generate intuitive and easy-to-understand policy scenarios.

This paper is part of a broader project, "Financial Programming 2.0" (FP 2.0), which is revisiting and modernizing the tools, models, and engagement strategy informing the Fund's decades-old workhorse approach to building and using macroeconomic frameworks, the "financial programming" (see Polak 1997 and papers cited therein). ${ }^{3}$ Financial programming and policies (FPP) is the only internal economics training course that is mandatory for all new IMF economists; it teaches an Excel-based approach to building baseline forecasts and conducting scenario-based policy analysis that has a minimal economic structure. The goal of the FP 2.0 project is to develop and apply a suite of models, from almost pure accounting to sophisticated general equilibrium models, and associated tools to facilitate integration of data and models to produce policy-friendly results. The engagement strategy aims to support the use and further development of these models by Fund staff and deliver them as technical macro assistance.

Why do we see a need for the FP 2.0 project? The primary reason is that the original FP is now incompatible with the medium-term business-cycle models that most advanced and emerging market countries now use for policy analysis (Polak 1997; Fukac and Pagan 2010). The original FP focus on detailed links and consistency among four sets of macroeconomic accounts (Ghosh and others 2005) came at the expense of theoretical and forecasting consistency (Easterly 2006). A well-designed, parsimonious FP 2.0 framework should overcome both shortcomings and remain tractable for most countries and most monetary and exchange rate regimes.

The rest of the paper is organized as follows: Section II describes the semistructural model, with a fiscal extension. Section III briefly discusses recent developments in Cambodia and their implications for calibrating the model. Section IV illustrates applications of the CAMFI model in assessing the economic impact of Covid-19 in Cambodia. Section V discusses caveats and potential extension of the model. Section VI concludes.

\section{The Macrofiscal Model}

The semistructural model we present here is like those many central banks use for policy analysis; in general, it corresponds to what Fukac and Pagan (2010) called the 3rd Generation $(3 \mathrm{G})$ of policy models. A steady-state model has been at the core of $3 \mathrm{G}$ frameworks: the

\footnotetext{
${ }^{3}$ The original FP framework was developed gradually, starting in the 1950 s, with a dual objective. (1) To ascertain how much credit and what type of adjustment policies a country needs when confronted by a balance of payments deficit that was difficult to finance from its own reserves: such calculations were guided by the monetary approach to the balance of payments (Polak 1991). (2) Operationally, to protect the IMF's own resources and ensure timely repayment through strict conditionality (Robichek 1967). The detailed system of interlinked external, monetary, fiscal, and national accounts supported the tracking of programs because it made it possible to set off "alarm bells" should national policies veer off the track agreed for the adjustment program.
} 
dynamics embedded in the model describe the transition from one steady state to another, so that solving the model produces a transitional steady-state solution for its variables - over time they will vary because movements from one point to another are not instantaneous. In addition, because some variables are taken to be exogenous and thus treated as determined outside the model economy, they need not be at their steady-state values in any period. As attention has been centered on the "gap" between the steady-state estimate, $z_{t}^{*}$, and the observed value, $z_{t}$, it therefore becomes natural to convert all the variables in the model to the gap format, producing what are often called "gap models" or "trend-gap models."

We have extended the model to incorporate a rudimentary fiscal and debt-accounting block, recast it to annual frequency, and calibrated it to capture the stylized facts of Cambodia's macroeconomic policies. It blends the New Keynesian emphasis on nominal and real rigidities and a role of aggregate demand in output determination with the real business cycle methods of DSGE modeling with rational expectations (Berg and others 2006). Rather than deriving the baseline model from strictly microeconomic foundations, we pragmatically allow both backward- and forward-looking expectations and substantial inertia in the equations to match the data.

The CAMFI model has five building blocks, as summarized in Figure 1 and detailed in Appendix C:

1. An aggregate demand or IS curve that relates the level of real activity to expected and past real activity, the real interest rate, the real exchange rate, the fiscal impulse, and foreign demand.

2. A price-setting or Phillips curve that relates current inflation to past and expected inflation, the output gap, the exchange rate, and oil prices. The relationships in (1) and (2) are independent of the monetary and exchange rate regime prevailing in the country under consideration.

3. A UIP condition for the exchange rate that incorporates the country risk premium. This equation can take multiple forms in the model as it is formulated to reflect the exchange rate regime - in the case of Cambodia, a heavily managed float that has stabilized the exchange rate at about 4,050 riels per US\$1, with an open capital account. ${ }^{4}$ Here, for the sake of parsimony, we chose to omit the external balances. The sizable CAD has been (over)financed by sustainable FDI inflows (IMF 2019). The UIP is also the model's reaction function for setting the domestic interest rate: the foreign rate plus a country risk premium (Obstfeld and others 2005). Thus, monetary policy passively accommodates movements in the world interest rate. The NBC has been keeping the exchange rate stable by a strict policy of no lending to the government - thus also signaling its independence. The monetary and exchange rate regime in our model is tailored to Cambodia's stylized facts and the equations are regime-dependent: for a country with an independent monetary policy we would need a different specification.

\footnotetext{
4 "The de jure exchange rate arrangement is a managed float. Given the high degree of financial dollarization, the National Bank of Cambodia (NBC) intervenes in the foreign exchange market to accommodate demand for riels and maintain exchange rate stability. The de facto exchange rate arrangement is classified as other managed.” IMF (2018c).
} 
4. The model is expanded to incorporate a fiscal policy reaction function. In practice, the Cambodian government has been following the "fiscal golden rule" for its current fiscal balance, while borrowing externally for some investment spending. ${ }^{5}$ This policy is equivalent to saying that the fiscal authority decides on a cyclically-adjusted primary deficit, taking into account the country's cyclical position and its announced gross debt target.

5. The model is closed with the usual debt accounting identity. The deficit is financed either by accumulating debt or dis-saving government deposits. Above-target debt increases the risk premium and thus raises the neutral real interest rate, and vice versa.

\section{Figure 1. Key Links in the Macrofiscal Model}

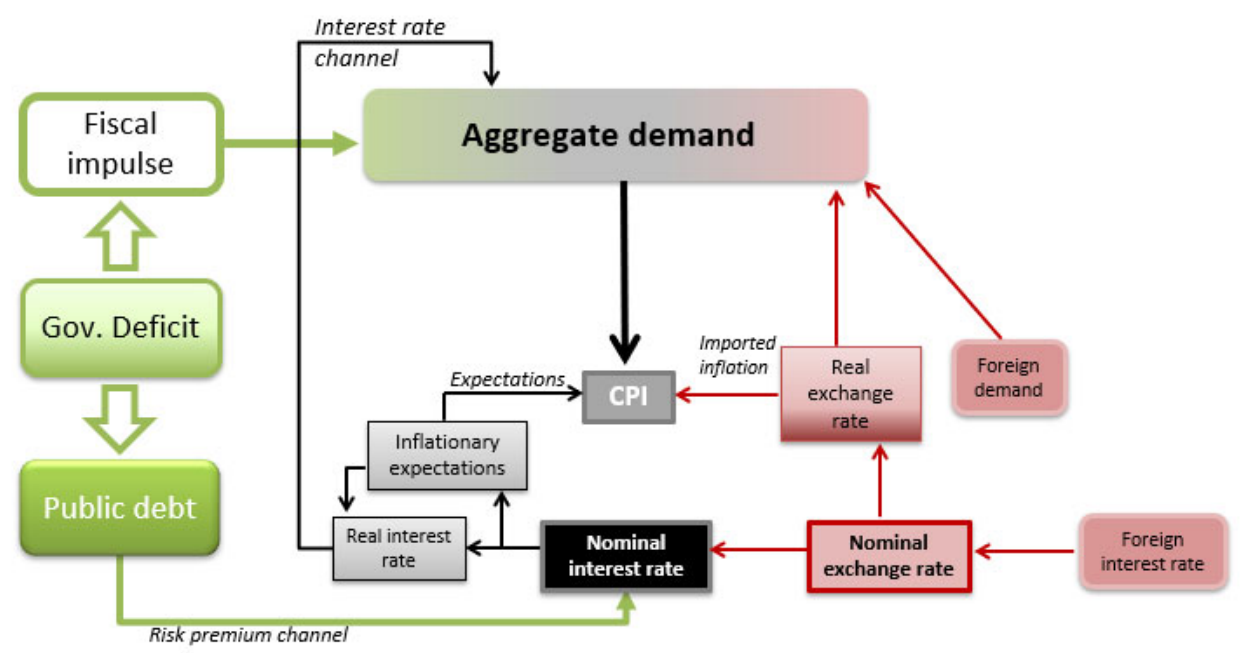

Source: The authors.

\section{A. Aggregate Demand}

The aggregate demand relationship — the IS curve-links the domestic output gap to past and expected output gaps, monetary conditions, the fiscal stance, and the foreign output gap:

$\hat{y}_{t}=a_{1} \hat{y}_{t-1}+a_{2} E_{t} \hat{y}_{t+1}-a_{3} m c i_{t}+a_{4} f_{t}^{i m p}+a_{5} \hat{y}_{t}^{*}+\varepsilon_{t}^{y}$,

where $\hat{y}_{t}$ is the output gap, defined as the deviation of the log of real output from its trend; $m c i_{t}$ denotes the real monetary conditions index; $f_{t}^{i m p}$ is the fiscal impulse, $\hat{y}_{t}^{*}$ is the foreign output gap, and $\varepsilon_{t}^{y}$ is an aggregate demand shock.

\footnotetext{
${ }^{5}$ The current balance is the difference between current revenue and current expenditure and the "fiscal golden rule" states that over the economic cycle the government should borrow only to invest, not to fund current spending (see, e.g., HM Treasury 2008).
} 
All parameters - $a_{i}, b_{i}, e_{i}, f_{i}$, and $g_{i}$ - have positive values and $E_{t}$ denotes model-consistent ("rational") forward-looking expectations. The gaps, denoted with "hats," are calculated as differences of the actual, observed variables from their estimated trends, denoted with tildes,

$$
\hat{x}_{t}=x_{t}-\tilde{x}_{t}
$$

The real monetary conditions index $(\mathrm{mci})$ is defined as a weighted average of deviations of the real interest rate, the credit risk premium, and the real exchange rate from their trends:

$$
m c i_{t}=a_{6}\left(\hat{r}_{t}+c r_{-} \text {prem }\right)+\left(1-a_{6}\right)\left(-\hat{z}_{t}\right),
$$

where $\hat{r}_{t}$ is the deviation of the real interest rate $\left(\hat{r}_{t}=i_{t}-E_{t} \pi_{t+1}-\tilde{r}_{t}\right)$ from its trend (neutral, $\tilde{r}_{t}$ ) level; cr_prem $_{t}$ is the credit risk premium; and $\hat{z}_{t}$ is the deviation of the real exchange rate from its trend.

What kind of interest rate do we have in mind? As long as the term and risk premiums for various maturities and financial instruments evolve in tandem, we can work with the shortterm, interbank interest rate so that innovations are transmitted along the yield curve. ${ }^{6}$ The real interest rate, $r_{t}$, applies only to private debt service; it reflects, among other factors, the country risk premium and external financial developments. Another real interest rate, $r_{t}^{g o v}$, in the model applies only to concessional borrowing by the government; it is low and stable. As is discussed below, because Cambodia's public debt is all on concessional terms, it is reasonable to disconnect these two interest rates, especially since the interest rate on public debt was stable even through the global financial crisis (GFC).

The real exchange rate is defined as the nominal exchange rate adjusted for differences in domestic and world price levels, $z_{t}=s_{t}+p_{t}^{*}-p_{t}$, where $s_{t}$ are units of domestic currency (for Cambodia, the riel) per US dollar; $p_{t}^{*}$ is the foreign and $p_{t}$ the domestic CPI index. Thus, an increase in $z_{t}$ implies a more depreciated, and a decrease a more appreciated, domestic currency in real terms.

The fiscal impulse, $f_{t}^{i m p}$, defined as the change in the cyclically-adjusted balance, $c a d_{t}$, indicates whether current fiscal policy is adding to or subtracting from aggregate demand (see more on the cad variable in Section D. The fiscal impulse also reflects movements in the debt target or in the discretionary changes in the debt ratio:

$$
f_{t}^{i m p}=\left(\operatorname{cad}_{t}-\operatorname{cad}_{t-1}\right)+f_{4} \varepsilon_{t}^{b^{t a r}} \pm f_{5} \varepsilon_{t}^{b}
$$

where $\varepsilon_{t}^{b^{t a r}}$ is a shock to the debt target and $\varepsilon_{t}^{b}$ to the debt ratio. The former makes it possible to capture the expansionary effect of an announcement of a higher or lower debt

\footnotetext{
${ }^{6}$ See Bulír and Vlček, forthcoming. Assumption of a stable factor greatly simplifies the model, making it unnecessary to build an explicit term structure of interest rates - most private-sector lending in Cambodia has a maturity of at most one year. In fact, the terms for private sector loans of various maturities have been relatively stable.
} 
target - the agents will expect a sequence of corresponding positive or negative future fiscal impulses and adjust their expected spending accordingly. The latter makes it possible to model the impact of debt changes as either traditional Keynesian contractionary stabilizations $\left(f_{5}>0\right)$ or non-Keynesian expansionary stabilizations $\left(f_{5}<0\right)$ as defined by Alesina and Ardagna (2010). While the model does not detail the transmission mechanism, based on expert judgment it is possible to design fiscal stabilization scenarios as contractionary, expansionary, or growth-neutral $\left(f_{5}=0\right) .^{7}$

Monetary policy affects aggregate demand through the real exchange rate and the real interest rate gaps, as aggregated in the monetary conditions index, $m c i_{t}$. Tighter monetary policy (a higher $m c i_{t}$ ) reduces the output gap either through a higher real interest rate (a higher $\hat{r}_{t}$ ) or an appreciated real exchange rate (a lower $\hat{z}_{t}$ ). Fiscal policy directly affects aggregate demand through the fiscal impulse - the parameter $a_{4}$ is equivalent to the impact multiplier (see Appendix B for a discussion of the value of the multiplier).

\section{B. Aggregate Supply}

The aggregate supply block, the Phillips curve, links inflation to backward- and forwardlooking expectations of inflation, to real marginal costs, and to oil prices:

$$
\begin{aligned}
& \pi_{t}=b_{1} \pi_{t-1}+\left(1-b_{1}\right) E_{t} \pi_{t+1}+b_{2} r m c_{t}+b_{3} \Delta o i l_{t}+\varepsilon_{t}^{\pi} \\
& r m c_{t}=b_{4} \hat{y}_{t}+\left(1-b_{4}\right) \hat{z}_{t} .
\end{aligned}
$$

Current period inflation, $\pi_{t}$, depends on forward-looking inflation expectations $\left(E_{t} \pi_{t+1}\right)$, backward-looking expectations $\left(\pi_{t-1}\right)$, the real marginal costs $\left(r m c_{t}\right)$, and a change in dollar-denominated oil prices adjusted for exchange rate appreciation or depreciation, $\Delta o i l_{t}$. The term rmc captures the weighted average of the real exchange rate gap and the output gap; in general, one can relate the real marginal cost for domestic producers to the output gap, $\hat{y}_{t}$, and those for importers to the real exchange rate gap, $\hat{z}_{t}$. The calibrated value of $b_{1}$ is our best guess about the share of backward-looking agents in the price-setting process. The product $b_{2} \cdot b_{4}$ measures the slope of the Phillips curve with respect to the output gap.

As is common in models that are designed to capture business cycle fluctuations, aggregate supply is largely an exogenous process. The economy grows along a calibrated potential output path that can be altered only marginally by movements in the equilibrium real interest rate. Specifically, in our model higher-than-targeted public debt raises both the country risk premium and the equilibrium interest rate, thus depressing the rate of growth of potential output. We discuss the debt-to-potential-growth nexus in Section II.D.

\footnotetext{
${ }^{7}$ In a traditional Keynesian fiscal stabilization, either through higher taxes or lower spending, lower debt $\left(\varepsilon_{t}^{b}<\right.$ 0 ) will cause a negative fiscal impulse, hence, $f_{5}>0$. In what circumstances could stabilization be expansionary $\left(f_{5}<0\right)$ ? Some economists have argued that a fiscal adjustment today removes expectation of future harsher adjustments or future tax hikes, thus stabilizing expectations, increasing consumer expected disposable income, boosting the confidence of investors, and therefore stimulating private demand (Giavazzi and Pagano 1996).
} 


\section{The Exchange Rate, Uncovered Interest Rate Parity, and the Policy Reaction Function}

The universe of exchange rate regimes requires appropriate equations to capture their role. Moreover, the specifications must be consistent with the monetary policy regime. ${ }^{8}$ Fortunately, there are tested versions of these equations for all regime combinations. Cambodia's combination is straightforward: a heavily managed exchange rate with an open capital account. From mid-2008 the riel-to-dollar rate oscillated around a mean of about 4,050 riels and we thus treat this value as an implicit but widely understood exchange rate target. We assume that NBC international reserves are sufficient to keep the exchange rate stable. Thus, in the model we treat the exchange rate regime as a de facto peg.

It is useful to recall what a credible exchange rate commitment implies for competitiveness: the country cannot restore price competitiveness by devaluing the nominal exchange rate. Should the real exchange rate become misaligned-due to either a productivity shock or higher domestic inflation relative to its trading partners - the eventual realignment must come through lower-than-trading-partner wage and price inflation, i.e., internal devaluation. The peg is then effectively equivalent to a price-level targeting regime that ensures that purchasing power parity (PPP) holds in the medium term; thus, in our notation time subscripts are not necessary:

$$
\Delta \tilde{z}=\Delta \tilde{S}+\tilde{\pi}^{*}-\tilde{\pi}
$$

where $\tilde{z}$ denotes the trend rate of growth of the real exchange rate, i.e., "equilibrium" appreciation or depreciation; $\tilde{s}$ is the trend rate of growth of the nominal exchange rate; and $\tilde{\pi}^{*}$ and $\tilde{\pi}$ indicate foreign and domestic inflation trends. As long as the nominal exchange rate is pegged $(\Delta \tilde{S}=0)$ and the country desires to keep price competitiveness at the current level (hence, $\Delta \tilde{z}=0$ ); foreign and domestic price levels have to grow at the same pace over the medium term, $\tilde{\pi}^{*}=\tilde{\pi}$. This result is equivalent, of course, to price-level targeting.

The UIP condition then pins down the domestic interest rate, $i_{t}$, since the NBC cannot pursue active monetary policy:

$$
i_{t}=\left(E_{t} s_{t+1}-s_{t}\right)+i_{t}^{*}+\operatorname{prem}_{t}+\varepsilon_{t}^{s}
$$

where $s_{t}$ is the nominal exchange rate defined in domestic currency terms per US dollar; $E_{t} s_{t+1}$ is the model-consistent expectations of the nominal exchange rate in period $t+1$ (as long as the peg remains credible, $\left.\Delta E_{t} s_{t+1}=0\right) ; i_{t}^{*}$ is the foreign nominal interest rate; prem $_{t}$ is the country risk premium, which is expected to increase or decrease with government debt compared to the target level; and $\varepsilon_{t}^{s}$ is the exchange rate shock.

\footnotetext{
${ }^{8}$ The Mundell-Fleming trilemma says that each country must choose between the objectives of free capital mobility, exchange-rate management, and monetary autonomy (Obstfeld, Shambaugh, and Taylor 2005)—only two can be pursued simultaneously.
} 


\section{The Fiscal Block}

The model is closed with an aggregated fiscal block that anchors expectations of the public about fiscal sustainability and links the fiscal policy (flow) variable with financing (stock) variables. Here, the fiscal authority decides on a sole policy variable, namely the cyclicallyadjusted primary balance, guided by the country's cyclical position and its announced gross debt target. We justify the aggregation by noting that our semistructural framework has an exogenously set supply side: the rate of potential growth does not depend on the mix of direct and indirect taxes, but it is calibrated and assumed to remain constant for the duration of the simulations, so that breaking down revenues or expenditures would be superficial with no feedback into the supply side. True, by aggregating all fiscal operations into a single variable we are foregoing the possibility of a granular analysis of multipliers and composition effects of fiscal policy, but in our view, decomposition is better left for a fully micro-founded DSGE model.

Fiscal authority decisions related to the golden rule can be simplified into two steps: (1) the policymaker decides on the cyclically-adjusted primary fiscal deficit, $\operatorname{cad}_{t}$. Because Cambodia's public borrowing has all been concessional, the government interest bill is not only small but is generally not sensitive to international rate movements and swings in risk premiums. ${ }^{9}$ (2) The policymaker decides how to finance the corresponding balance: either through debt accumulation or repayment, $\Delta b_{t}$, or through dissaving or accumulation of government deposits, $\Delta x_{t}$.

In line with the literature on fiscal rules, our fiscal policy reaction function has two competing objectives: to smooth output fluctuations, and to anchor gross public debt to a target, which is presently calibrated at 30 percent of GDP (Plödt and Reicher 2015). Regarding the former, the fiscal authority wants to avoid large swings in the balance compared to the last period, $\mathrm{cad}_{t-1}$, and also wishes to respond to a positive or negative output gap, $\hat{y}_{t}$, with a tighter or looser deficit. Regarding the latter, debt stabilization implies setting the cyclically-adjusted balance at a level consistent with the debt target, $c_{t} d_{t}^{\text {tar }}$, adjusted for the current-period deviation of debt from its target level, $b_{t}^{d e v} .{ }^{10}$ Intuitively, lower-than-targeted debt $\left(b_{t}^{\text {dev }}<0\right)$ implies tighter fiscal policy, producing either a surplus or a smaller deficit than $\left(b_{t}^{d e v}=0\right)$, and vice versa:

$$
\operatorname{cad}_{t}=f_{7}\left(\operatorname{cad}_{t-1}-f_{10} \hat{y}_{t}\right)+\left(1-f_{7}\right)\left(\operatorname{cad}_{t}^{\text {tar }}-f_{8} b_{t}^{\text {dev }}\right)+\varepsilon_{t}^{c d}
$$

The obvious implication of these two competing objectives is that in the short run neither is fully achievable: while the fiscal authority may want to stimulate the economy by running a

\footnotetext{
${ }^{9}$ Recall that the market interest rate for the private sector is different from the interest rate on public debt.

10 The cyclically-adjusted budget balance is the balance that would obtain when GDP reaches its potential. The cyclically-adjusted measure better describes the stance of fiscal policy than the headline balance, as it removes the endogenous components of spending and revenues. In our model we use the common definition of the cyclically-adjusted balance, see Fedelino and others (2009): $c a d=-\epsilon \hat{y}$, and our calibration of $\epsilon$ follows Price and others (2015).
} 
larger cyclically-adjusted deficit, it would be held back by debt concerns. Deviation from the debt target, $b_{t}^{\text {dev }}$, is a forward-looking process as the fiscal authority assesses both the current deviation and the expected future path, where the debt target itself could be time-varying:

$$
b_{t}^{\text {dev }}=f_{9}\left(b_{t}-b_{t}^{\text {tar }}\right)+\left(1-f_{9}\right) E_{t} b_{t+1}^{\text {dev }} .
$$

Debt accumulation follows the usual law of motion:

$$
b_{t}=d_{t}+\Delta x_{t}+\left(1+\Delta s_{t}\right) b_{t-1} /\left(1+g_{t}\right),
$$

where $b_{t}$ is the debt-to-GDP ratio at year $t$, and $d_{t}$ is the overall deficit $\left(d_{t}>0\right.$ indicates a deficit, $d_{t}<0$ a surplus); $g_{t}$ is the growth rate of nominal GDP; $\Delta s_{t}$ denotes the revaluation term of foreign-currency-denominated concessional debt; and $\Delta x_{t}$ denotes changes in government deposits.

The choice of financing between changes in the stock of debt and the stock of deposits at the central bank goes beyond a simple accounting exercise - certainly in Cambodia.

Disbursements by external lenders are relatively infrequent and mostly related to donor-

funded investment projects. In the absence of short-term treasury bills or borrowing from the banking system, to finance its day-to-day operations the treasury has built a buffer of government deposits at the NBC. ${ }^{11}$ This brings up a somewhat peculiar feature of Cambodia's fiscal operations: in the short run gross debt is "passive," reflecting the donordriven supply of loans. In contrast, government deposits are an "active," domesticallydetermined variable. In good times, the fiscal authority borrows more than is needed and saves the proceeds in the central bank, effectively pre-financing future debt needs. In bad times, it draws down these deposits without needing to approach either concessional lenders or capital markets. The fiscal authority therefore targets a level of deposits that guarantees current and future payment of its bills, keeping in mind the cyclical position of the economy. We specify the following law of motion for government deposits, $\Delta x_{t}$ :

$$
\Delta x_{t}=g_{2} \Delta x_{t-1}+\left(1-g_{2}\right)\left(\Delta x_{t}^{t a r}+g_{3} \hat{y}_{t}+g_{4}\left(p d_{t}-p d_{t}^{t a r}\right)\right)+\varepsilon_{t}^{x},
$$

where $x_{t}^{t a r}$ is the desired level of government deposits, and based on the historic average we calibrate its steady-state value at 8 percent of GDP. The policymaker will smooth out deposits around the target, accumulating deposits when the economy operates above its potential and "decumulating" when it operates below; and then accumulates or decumulates as needed whenever the primary deficit deviates from the debt-stabilizing level.

\footnotetext{
${ }^{11}$ The impact of changes in government deposits (negative net claims on government) on private sector lending depends on where government savings are deposited. If they are deposited in the central bank, as in Cambodia, the impact on private sector lending is zero. If they are deposited in commercial banks, their withdrawal would crowd out private lending and the net government position will become less negative. As long as money supply remains unchanged, private sector credit would be a residual item and would have to decline one-for-one with the drawdown of government deposits.
} 
A further reason to separate the financing items is their differential impact on the risk premium and thus on the neutral real interest rate. Empirically, countries with larger gross debt-to-GDP ratios have had to offer higher yields to investors (Engen and Hubbard 2004 and Jaramillo and Weber 2012). Countries during periods of financial turmoil, as in a cyclical downswing or with a primary deficit temporarily above the debt-stabilizing level, should be better off drawing down buffer stocks of deposits rather than borrowing at higher, nonconcessional rates..$^{12} \mathrm{~A}$ deposit-dissaving scenario would limit the impact on the risk premium and thus keep the equilibrium real interest rate lower than in the scenario with higher gross debt. Ultimately, higher equilibrium real interest rates limit growth because fewer investment projects are deemed profitable (Schumacher and Żochowski 2017).

\section{ReCEnt ECONOMIC DeVElopments in CAMbodia AND CAMFI CALIBRATION}

With monetary policy limited by dollarization, the authorities have relied on fiscal policy to stabilize the economy. After sketching out the main stylized facts, we explore the implications for calibration of our model.

\section{A. Recent Economic Developments}

Since the internal conflict ended in 1998 , followed by liberalization of trade and the capital account, Cambodia has averaged real GDP growth of $73 / 4$ percent, with average inflation of about 4 percent. Growth has been driven by garment exports, tourism, and construction, much of it funded by foreign investment (Chart 1 in Figure 2). Openness to trade and capital flows under a stable exchange rate, while boosting growth, has also increased the country's external vulnerability, especially given its narrow economic base and increasing dependence on foreign funding. Cambodia does not borrow on private capital markets.

The economy is almost completely dollarized, which limits NBC monetary policy options (Chart 2 and 3). In 2019, more than 90 percent of saving, loans, and economic transactions were in US dollars, with the exchange rate averaging about 4,050 riel per dollar. Robust FDI inflows have contributed to f gross international reserves equivalent to about 7 months of imports. Reserves have been assessed as adequate when measured against traditional metrics, but the IMF (2019) has encouraged some further accumulation.

\footnotetext{
${ }^{12}$ The empirical literature on aid agrees that donors, other than multilateral donors, act procyclically- they do not increase concessional disbursements during crises (Bulír and Hamann 2008; Pallage and others 2006; and Romero-Barrutieta and others 2015).
} 
Figure 2. Cambodia: Selected Stylized Facts

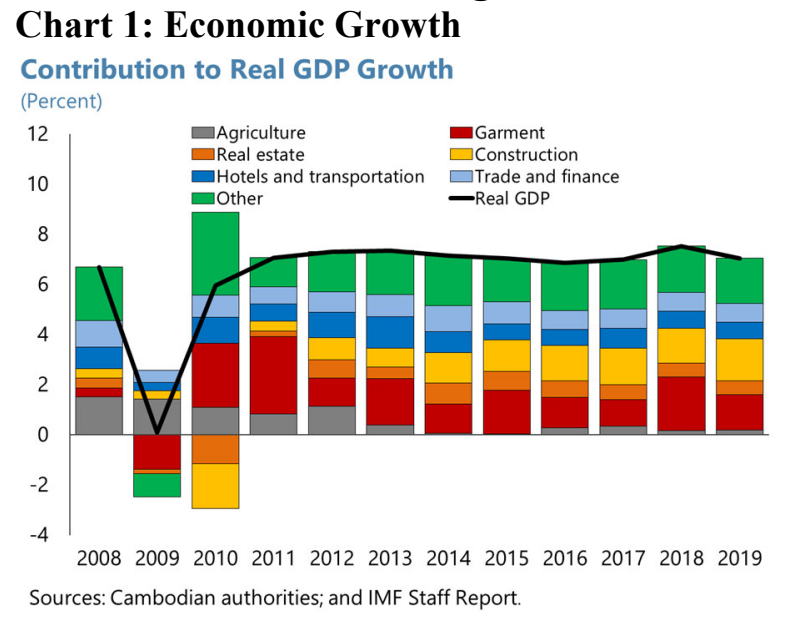

Chart 2: Dollarization

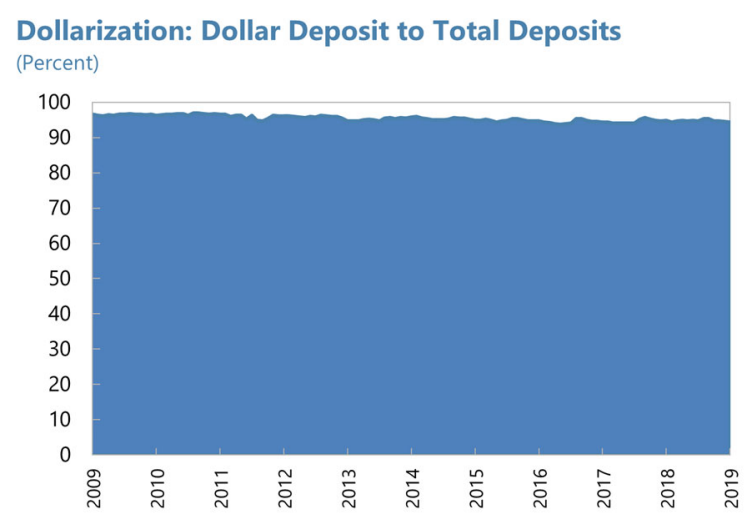

Chart 3 : The Exchange Rate

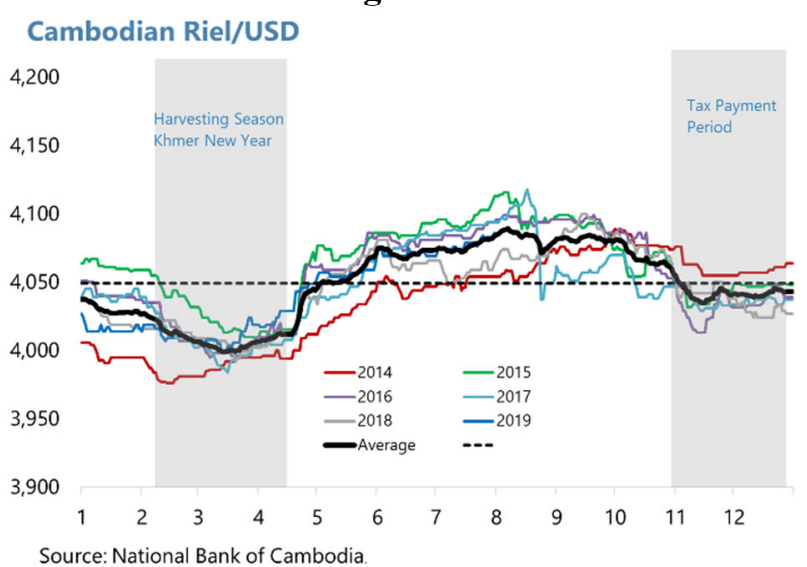

\section{Chart 5: The Fiscal Balance}

Cyclically-Adjusted Balance

(Percent of GDP)

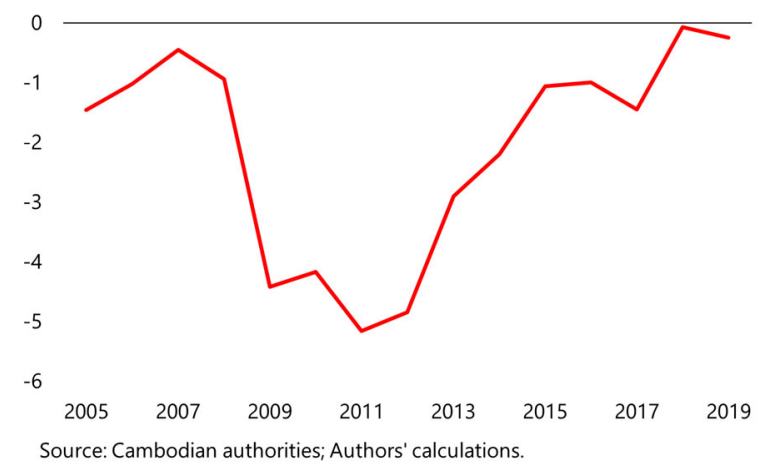

Sources: Cambodian authorities.

Chart 4: Revenues and Expenditures

Fiscal Operations

(Percent of GDP)

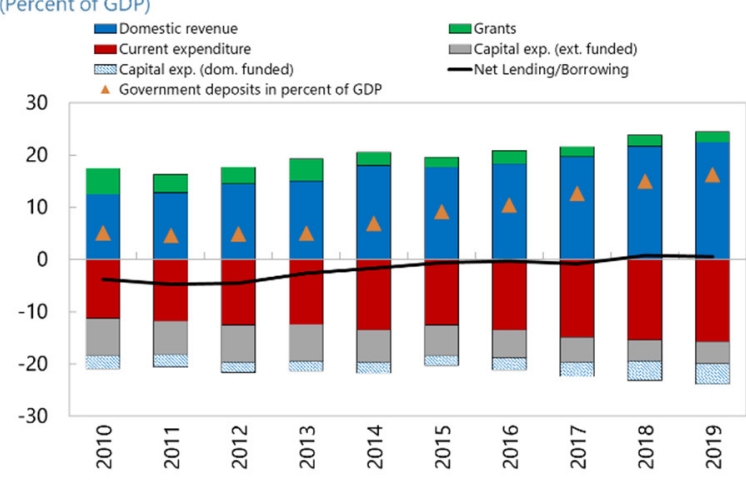

Sources: Cambodian authorities; IMF Staff Report

\section{Chart 6: Net Lending}

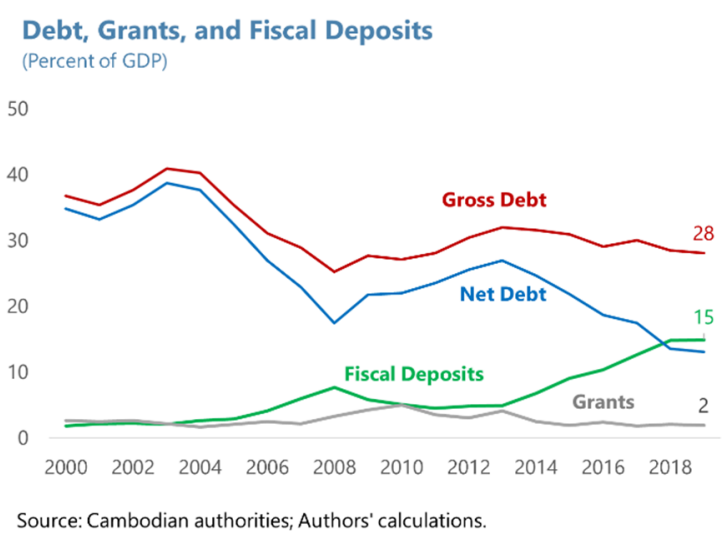

Given the monetary regime, the burden of macroeconomic management rests largely on fiscal policy. Fiscal reforms have improved revenue collection and spending efficiency (IMF 2018a), resulting in a series of small deficits and surpluses. Operationally, the government has been running a small surplus on the current balance, with foreign grants and concessional lending covering most capital expenditures (Chart 4). The cyclically-adjusted balance has improved significantly since the GFC (Chart 5). Gross external debt has stabilized at about 30 percent of GDP, and by 2019 the government had deposits equal to about 15 percent of 
GDP at the NBC (Chart 6). ${ }^{13}$ Net public external debt declined from its peak of 39 percent of GDP in 2003 to 13 percent in 2019. As virtually all borrowing was on concessional terms, public debt service in 2015-19 averaged only about 0.3 percent of GDP. Nevertheless, the authorities are anxious to better understand the transmission channels and simulate the impact of large macroeconomic shocks on fiscal sustainability. ${ }^{14}$ The biggest current shock is, of course, Covid-19.

\section{B. Calibration}

The answers any model would give depend crucially on its parameter values. We calibrate the CAMFI to capture the country-specific features as suggested by Berg, Karam, and Laxton (2006). Model adequacy for policy analysis depends primarily on how well it captures the main transmission channels. For example, we expect the model to provide reasonable estimates of the sensitivity of net public debt to the business cycle or exchange rate passthrough.

To this end, our choice of parameters is based on four considerations: (1) Whenever it is meaningful, we assess econometrically the relationships or base the calibration on expert judgment. This approach is suitable, for example, to assess the persistence of such variables as the output gap. (2) Where the necessary data are available, we compare the model impulse response functions with empirical evidence; for Cambodia, however, empirical results are limited, see Rungcharoenkitkul, 2012. (3) We assess whether the model can produce such unobserved variables as potential output or the equilibrium real exchange rate that would be consistent with the generally accepted narrative about the Cambodia business cycle (IMF 2018b, and 2019). (4) Finally, the model must be able to generate reasonable recursive forecasts, with inflation and output converging to their steady state values over the medium term.

\section{Test Driving the CAMFI}

In this section we validate our calibration against the generally accepted narrative based on three considerations: impulse response functions, estimation of unobserved variables, and recursive forecasts.

\footnotetext{
${ }^{13}$ Cambodia has a formal external debt ceiling of 40 percent of GDP and a domestic debt ceiling of 15 percent but has not borrowed domestically at all.

${ }^{14}$ Several such shocks were explored during past technical assistance visits. For example, in February 2020 the European Commission decided to partially withdraw Cambodia's preferential access to the EU market "due to the serious and systematic violations of human rights principles," https:/ec.europa.eu/commission/

presscorner/detail/en/ip_20_229. On January 1, 2020, casinos in the seaside resort of Sihanoukville were asked to shut down their online operations, causing massive employment and real estate losses.

https:/www.reuters.com/article/us-cambodia-gambling/thousands-lose-jobs-casinos-shut-as-cambodia-bansonline-gambling-idUSKBN1YZ0O3.
} 


\section{Impulse Responses}

To assess the realism of the model's transmission mechanism, we explore its properties in terms of three impulse responses: (1) a shock to aggregate demand: an unexpected increase in the domestic output gap by 1 percentage point for one year; (2) a financial shock: an unexpected increase in the country risk premium by 1 percentage point for one year; and (3) unexpected temporary and permanent fiscal expansions: a shock to the primary deficit by 1 percentage point without and with a change in the debt target.

The impulse responses from a calibrated model need to correspond to the empirical evidence available. Because empirical studies using Cambodian data are few, we rely on panel empirical studies (Fatás and Mihov 2001; Ilzetzki and others 2013; and Owyang and others 2013) for the shape of the impulse responses and on Batini and others (2014) for the fiscal multipliers. Such studies provide stylized facts that our simulations attempt to mimic.

What are some of those stylized facts? (1) Because empirical effects of fiscal actions are long-lasting, stretching beyond seven years, the return to the steady state needs to be much slower than in the monetary model outlined by Berg and others (2006). (2) The impact of fiscal policy actions on output depends on the monetary regime- - when exchange rates are fixed, the multipliers tend to be higher than when exchange rates float. (3) The fiscal space matters: multipliers have been found higher in countries that could temporarily support higher debt-to-GDP ratios without sustainability concerns. (4) As long as one expects the debtor country to honor its debts, debt today will have to be serviced through consolidation in the future, which means the long-run multipliers will be around zero. ${ }^{15}$

\section{Aggregate Demand}

Figure 3 illustrates the implications of a positive aggregate demand shock in Cambodia. Windfall taxes and lower cyclical spending push the headline primary balance into surplus (recall that fiscal deficits are recorded as positive numbers), but the cyclically-adjusted primary balance first swings into a deficit because of the positive output gap. The debt-toGDP ratio falls as the numerator expands; however, the fiscal authority will bring it back to the steady state through a series of expected future deficits. Neither the nominal exchange rate nor the nominal interest rate moves because the former is stabilized by central bank liquidity operations and the latter is linked to the world interest rate through the UIP. However, domestic inflation reacts to the output gap, causing the real exchange rate to appreciate relative to the steady state and creating a contractionary monetary stance. Though the output gap closes in about five years, gross debt and inflation take 10 years to return to the steady state.

\footnotetext{
${ }^{15}$ Positive long-run fiscal multipliers can happen: A country may invest loan proceeds into physical or human capital that would yield positive returns long after the initial deficit-financed public spending or tax cut.
} 
Figure 3. Dynamic Responses of Fiscal Variables, GDP, Real Exchange Rate, and Inflation to a Surprise One-Year 1 Percentage Point Increase in the Output Gap (Shock-minus-Control Responses)
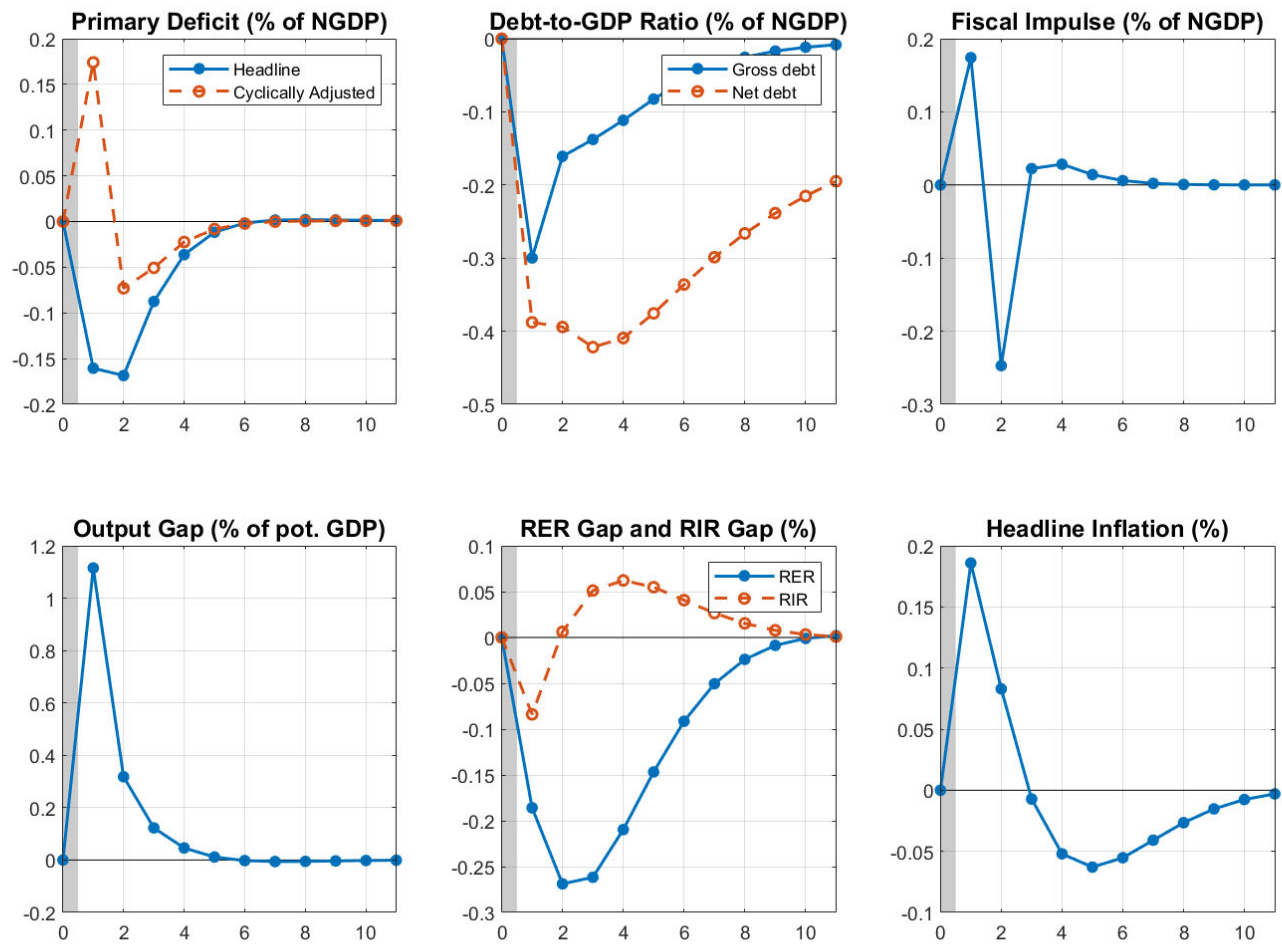

Notes: The figure depicts dynamic responses to an increase in the domestic output gap at $t=1$; the fiscal impulse is measured as the difference between the cyclically-adjusted primary deficit in $t$ and $t-1$; the RER (real exchange rate) gap is measured as the difference between the current-period value of the real exchange rate and its equilibrium value of the real exchange rate; and the RIR (real interest rate) gap is measured as the difference between the current-period value of the real interest rate and the rate's equilibrium value.

Source: CAMFI, author's simulations.

\section{Risk Premium}

Figure 4 illustrates the implications of a short-lived monetary tightening abroad or a negative domestic confidence shock. The real domestic private-sector interest rate, $r_{t}$, accommodates the interest rate increase from abroad, tightening the monetary stance. The adverse output impact is relatively small compared to the increase in the debt-to-GDP ratio, so the fiscal authority tightens its stance, bringing the debt level back to the steady state. (Recall that the concessional rate applied to public debt is not affected by the risk premium moves.) It is worth noting that the return to the steady state takes more than 10 years, even though the initial risk- premium shock was for one year only. 


\title{
Figure 4. Dynamic Responses of Fiscal Variables, GDP, Real Exchange Rate, and Inflation to an Unexpected 1 Percentage Point Rise in the Country Risk Premium for One Year (Shock-minus-Control Responses)
}
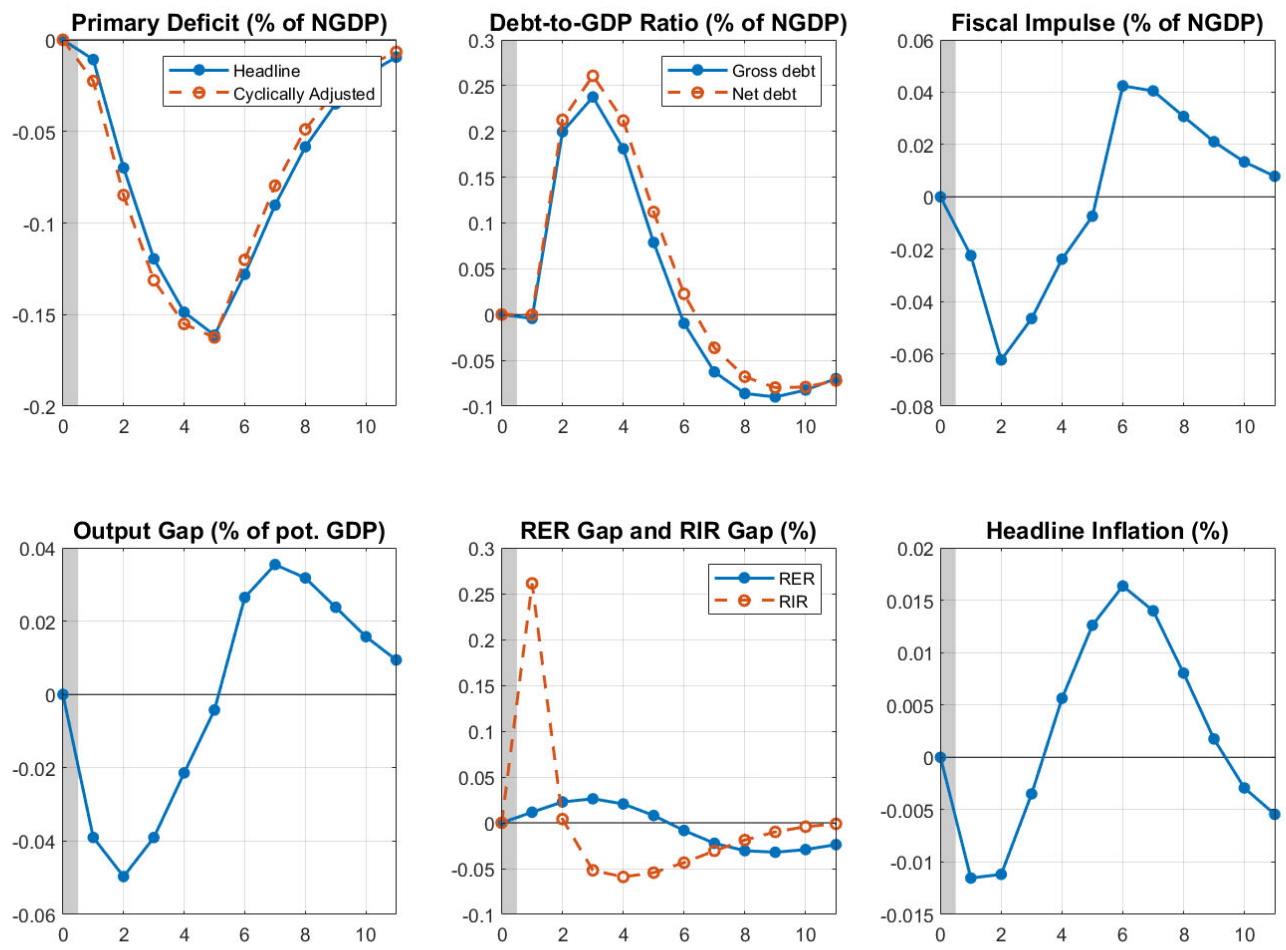

\begin{abstract}
Notes: The figure depicts dynamic responses to an increase in the primary deficit at $t=1$; the fiscal impulse is measured as the difference between the cyclically-adjusted primary deficit in $t$ and $t$ - 1 ; the RER (real exchange rate) gap is measured as the difference between the current-period value of the real exchange rate and its equilibrium value; and the RIR (real interest rate) gap is measured as the difference between the current-period value of the real interest rate and the rate's equilibrium value.
\end{abstract}

Source: CAMFI, author's simulations.

\section{Fiscal Multiplier}

Figure 5 compares the implications of a one-period fiscal expansion - the primary deficit widens by 1 percent of GDP - in two hypothetical scenarios: (1) A temporary fiscal expansion implies that the fiscal authority will bring now-higher gross debt back to its target level and in doing so it will be guided by the fiscal policy reaction function. (2) Then a permanent fiscal expansion implies that the fiscal authority will permanently revise upward the debt-to-GDP target for the stimulus by 1 percentage point. While the impact multiplier is similar in both scenarios, whether the expansion is temporary or permanent has a profound impact on the long-run multiplier. While the long-term multiplier is zero for the permanent stimulus, it is negative for the temporary stimulus. With a temporary stimulus the fiscal authority needs a longer series of primary surpluses to bring debt back to its target, thus withholding aggregate demand. 
Figure 5. Dynamic Responses of Fiscal Variables, GDP, Real Exchange Rate, and Inflation to an Unexpected Temporary 1 Percentage Point One-Year Stimulus and an Unexpected One-Year Permanent Fiscal Stimulus

(Shock-minus-Control Responses)
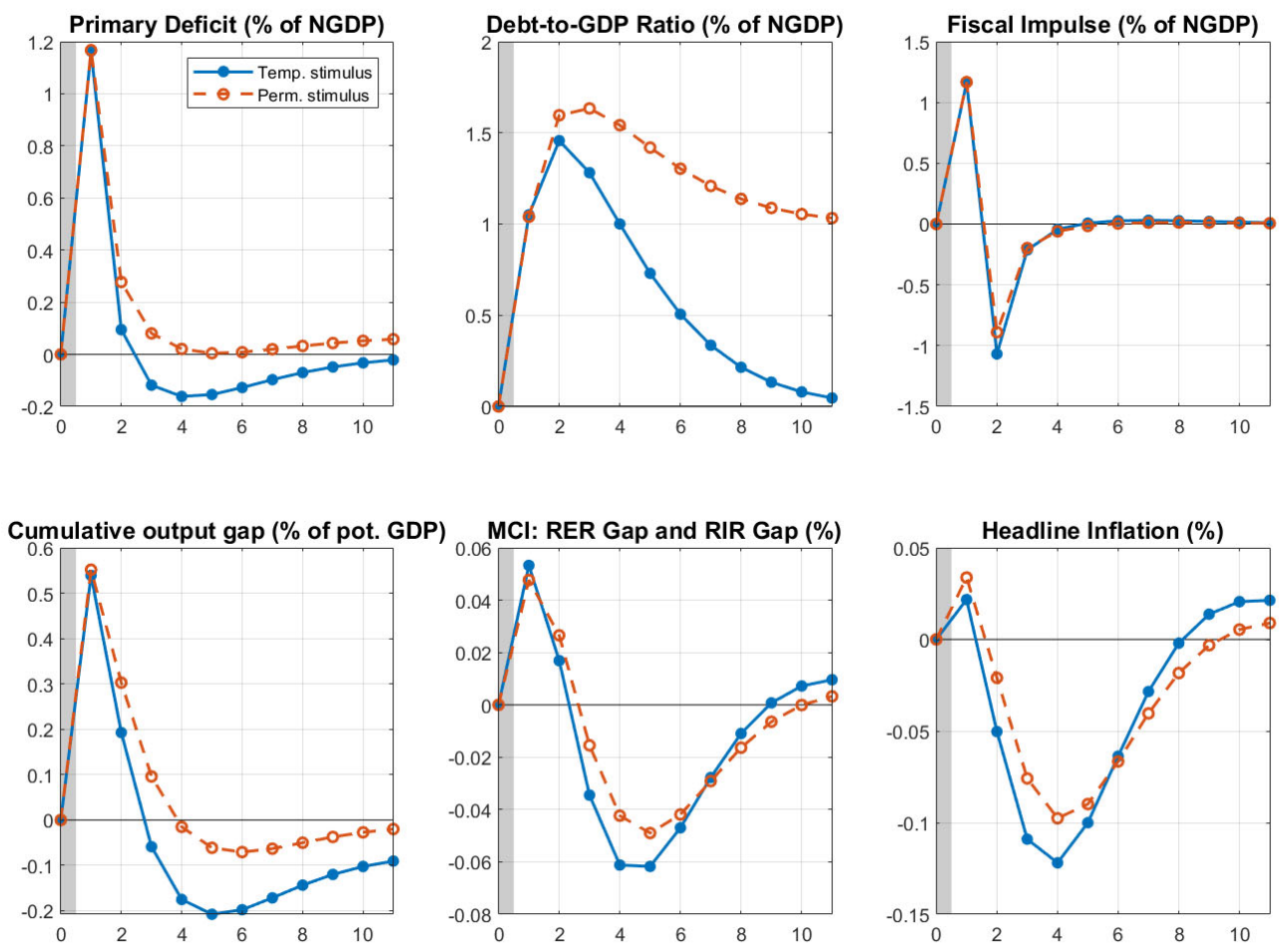

Notes: The figure depicts dynamic responses to an increase in the primary deficit at $t=1$; the fiscal impulse is measured as the difference between the cyclically-adjusted primary deficit in $t$ and $t$-1; the RER (real exchange rate) gap is measured as the difference between the current-period value of the real exchange rate and its equilibrium value; and the RIR (real interest rate) gap is measured as the difference between the current-period value of the real interest rate and the rate's equilibrium value.

Source: CAMFI, author's simulations.

\section{Multivariate Filter Results}

We believe that our multivariate-filter estimates for aggregate demand, aggregate supply, and fiscal variables are well-aligned with the typical narrative. We employ the model to estimate unobserved economic variables, the information in the observed variables, and the multivariate (Kalman) filter. The link between the observed and unobserved variables - the output, exchange rate, and interest rate gaps - is represented by the model itself. Conditional on the state form of the model and the observed variables, the multivariate filter can identify all unobserved variables and shocks. For linear systems, the Kalman filter represents an optimum estimate in terms of the least squares criterion (Hamilton 1994). As some variables are nonstationary, without finite value variances, we employ the diffuse Kalman filter (De Jong 1991). 
The questions we ask are straightforward: Are the filter-derived unobserved variables consistent with the generally accepted narrative about the Cambodian business cycle (as in IMF 2018b and 2019)? Can we use the estimates of unobserved variables - the gaps - to explain such observed variables as inflation, output, and fiscal developments?

Our results suggest that Cambodia's economy was overheated before the GFC, driven both by the imported low interest rate and the undervalued exchange rate (Figure 6). The estimates further suggest that the authorities reacted with a fiscal impulse in 2009; however, the growth slowdown in 2012 was to a large degree attributable to a negative fiscal impulse that was only partly reversed in 2013 . There seemed to be only very limited demand-side shocks postGFC.

Inflation peaked in 2008, driven by an overheated economy, an undervalued exchange rate, and the global food-price shock (Figure 7). Inflationary shocks dissipated quickly, however, and inflation remained a few percentage points above the level of Cambodia's trading partners. As a result, the riel appreciated relative to its equilibrium value, though to a lesser degree than estimated in IMF (2019). As in our demand-side estimates, the post-GFC period has been remarkably free of supply shocks.

Figure 6. Cambodia: Aggregate Demand and Its Components, 2002-19, Percent of GDP
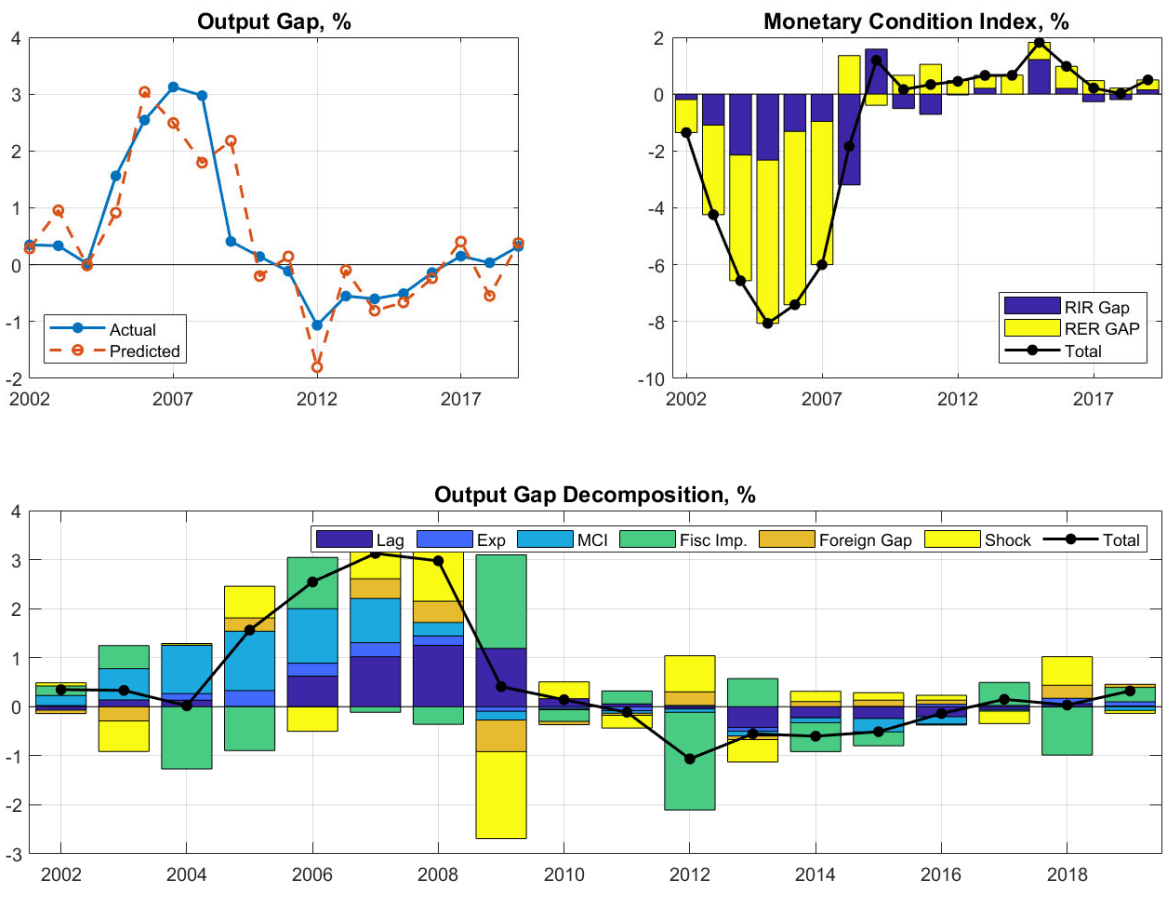

Note: A negative real exchange rate gap indicates an exchange rate that is overvalued relative to its trend value.

Source: CAMFI, author's simulations. 
Figure 7. Cambodia: Aggregate Supply and Its Components, 2002-19, Percent
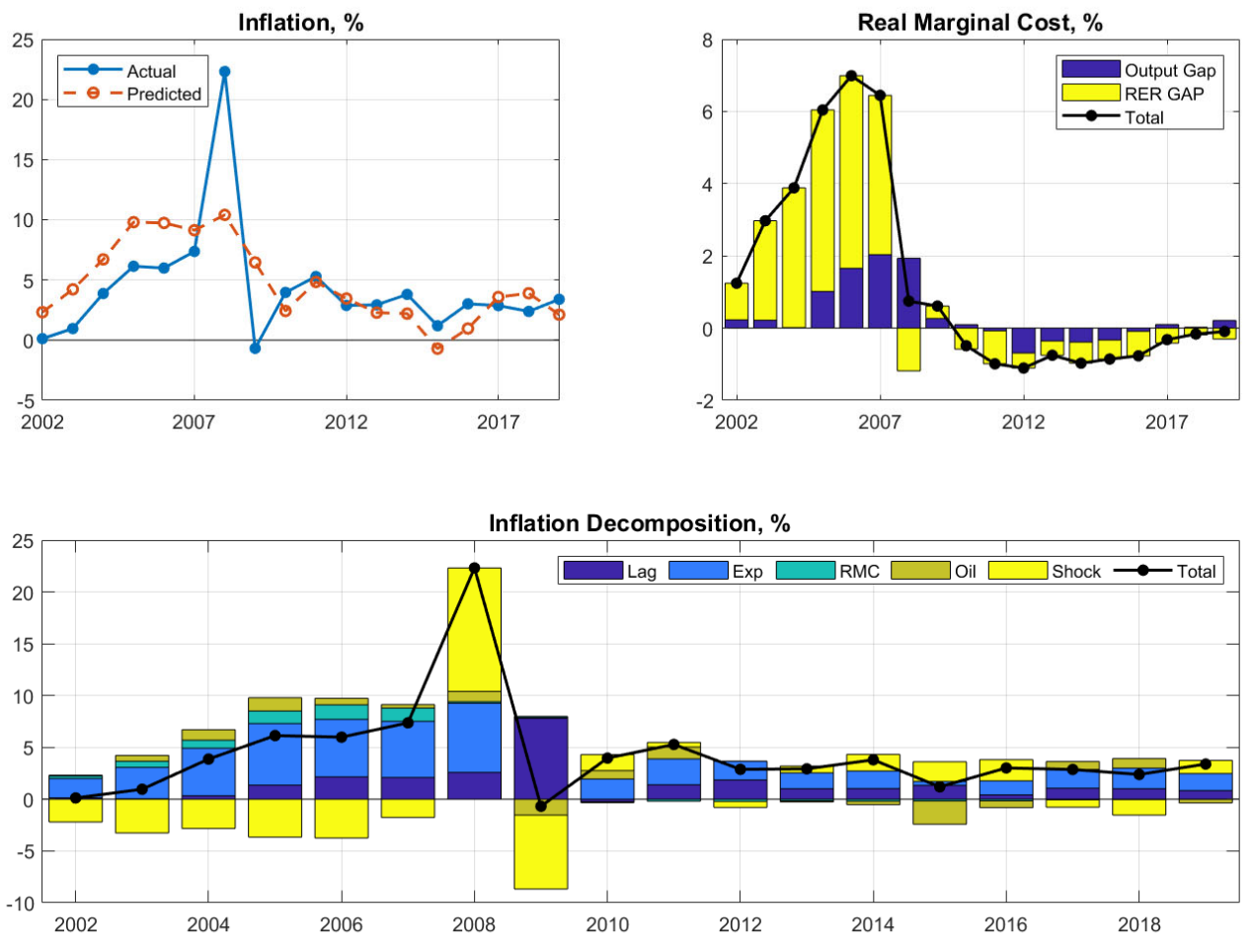

Source: CAMFI, author's simulations.

Post-GFC fiscal developments greatly benefitted from steady growth in real GDP. Cyclical smoothing - by about 2 percentage points of GDP — was apparent in 2010-12. Thereafter the government ran a tighter fiscal stance than envisaged by the calibration of the fiscal policy reaction function (see the purple bars). The stance allowed the government to accumulate sizable government deposits while keeping gross debt at the target level. In 2019 the actual deposit-to-GDP ratio was almost twice as high (15 percent) compared to our calibrated steady-state value (8 percent; Figure 2). 
Figure 8. Cambodia: Fiscal Balances, 2002-19, Percent of GDP
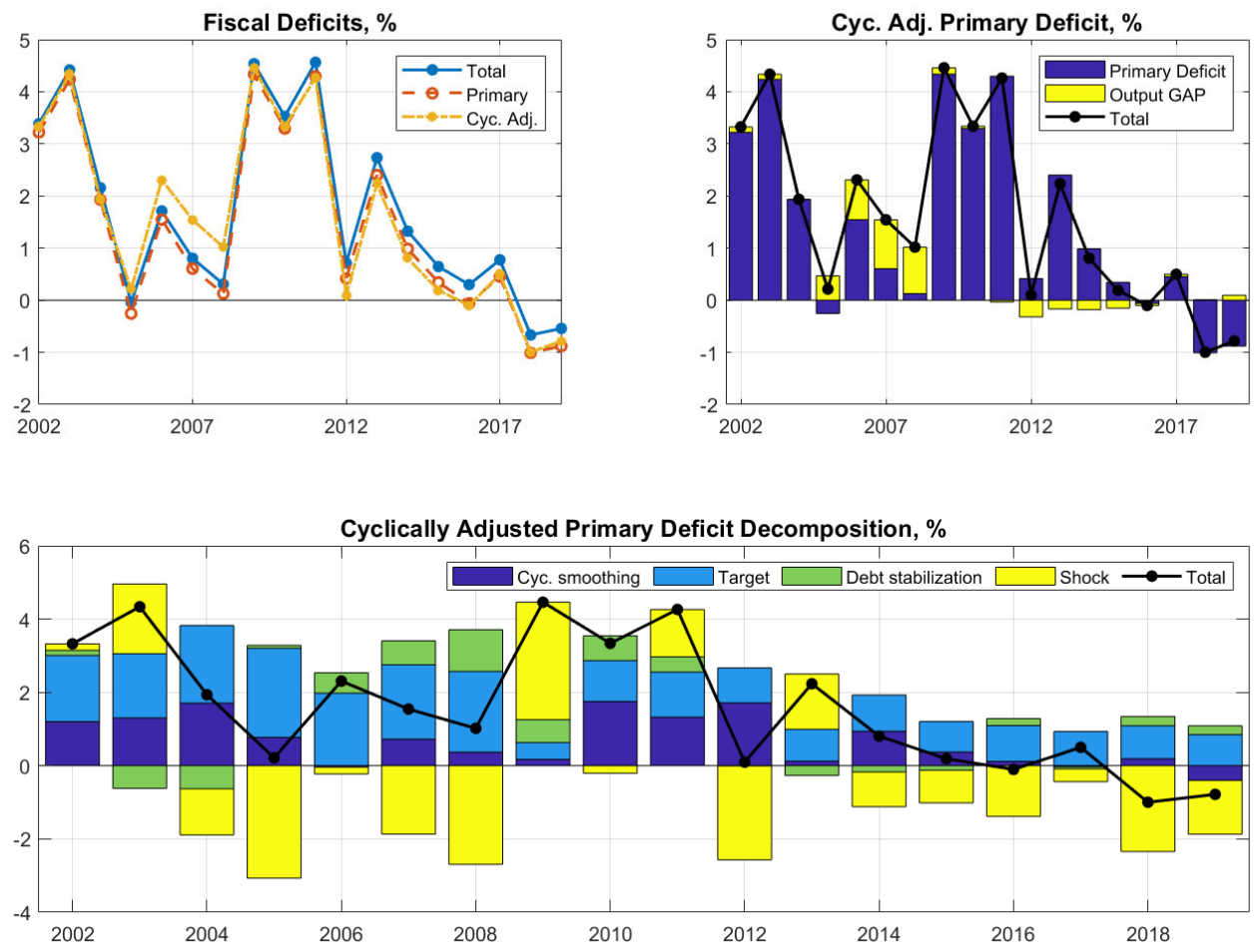

Note: A positive number indicates a deficit; a value of -1 for the primary balance in 2018 indicates a surplus of 1 percent of GDP.

Source: CAMFI, author's simulations.

\section{Recursive Forecasts}

Next, we use the model-identified unobserved variables to assess the model's predictive ability. Mechanically, we employ the Kalman filter to identify the initial conditions for each year $(t)$ and make a series of 8-years-ahead recursive forecasts. All domestic variables are forecast endogenously, but we use their actual realizations for foreign variables. We then shift the model-identified initial conditions by one year and make another 8-years-ahead forecast, and so on. Figure 9 summarizes all 17 of our recursive forecasts - from 2003 to 2019-forming a series of "spaghetti" charts for the variables of interest.

The model generates reasonable recursive forecasts: they predict most of the turning points in output and inflation. The missed turning points can be traced back to supply-side, external, and policy developments that are exogenous to our simple model, such as the post-conflict recovery of GDP in 2004-05; the global food price shock of 2007-08; and the post-GFC policy decision to accumulate fiscal deposits and drive down the net debt-to-GDP ratio. Our chosen form of the UIP captures the interest rate and exchange rate nexus very well. The fiscal variables, especially during the fast-growth pre-GFC and post-2012 periods, are in line with the goal of keeping gross debt at about 30 percent of GDP while bringing net debt lower during cyclical upswings. 
Figure 9. Cambodia: Recursive Forecasts, 2003-19
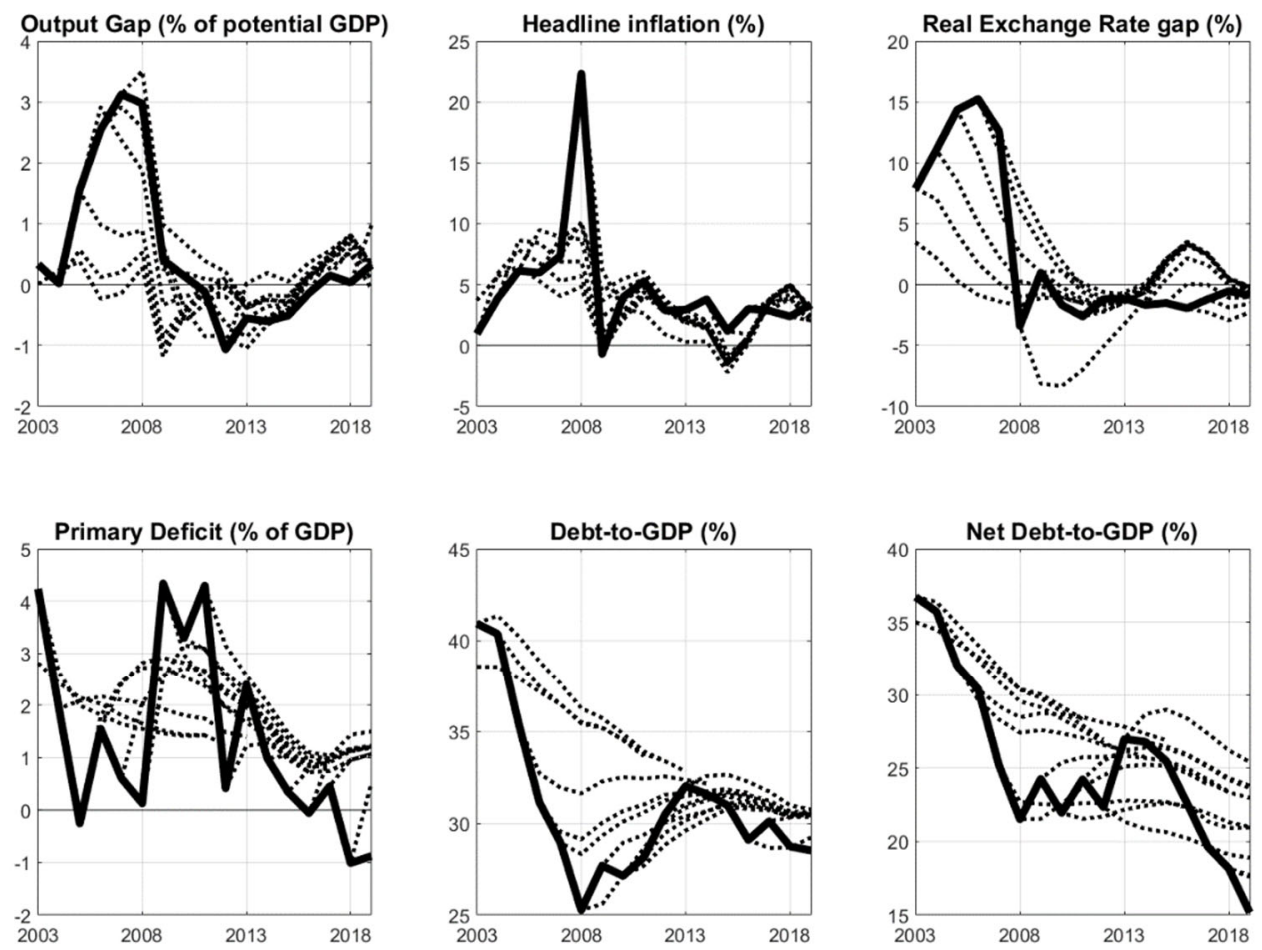

Notes: The figure shows recursive forecasts for the main macroeconomic variables. All domestic variables are forecast endogenously but their actual realizations are used for foreign variables.

Source: CAMFI, author's simulations.

\section{A Policy-Relevant Exercise}

We now test the model on a counterfactual scenario of the economic impacts of the Covid-19 pandemic on Cambodia. We hasten to say that the scenario does not represent official macroeconomic projections of the IMF or Cambodian authorities and was designed primarily to showcase the scenario-making and reporting capabilities of the model: all judgmental assumptions are entirely our own. Indeed, the scenario paints a more pessimistic picture of the pandemic than the April 2020 World Economic Outlook(WEO) projection for Cambodia.

\section{A. Scenario Building and Assumptions}

The analysis depends on three layers of assumptions: (1) a recession in its trading partners affects demand for Cambodia's exports and leads to a collapse in tourist arrivals; (2) a second-round impact on domestic demand and supply that affects the country risk premium, working through the expectations chanel; and (3) a fiscal response as the government introduces a fiscal stimulus to mitigate the impact from the previous two layers. The scenario is then compared with the baseline built around the pre-Covid-19 WEO growth projection. 
Figure 10: Simulation Results, 2020-30
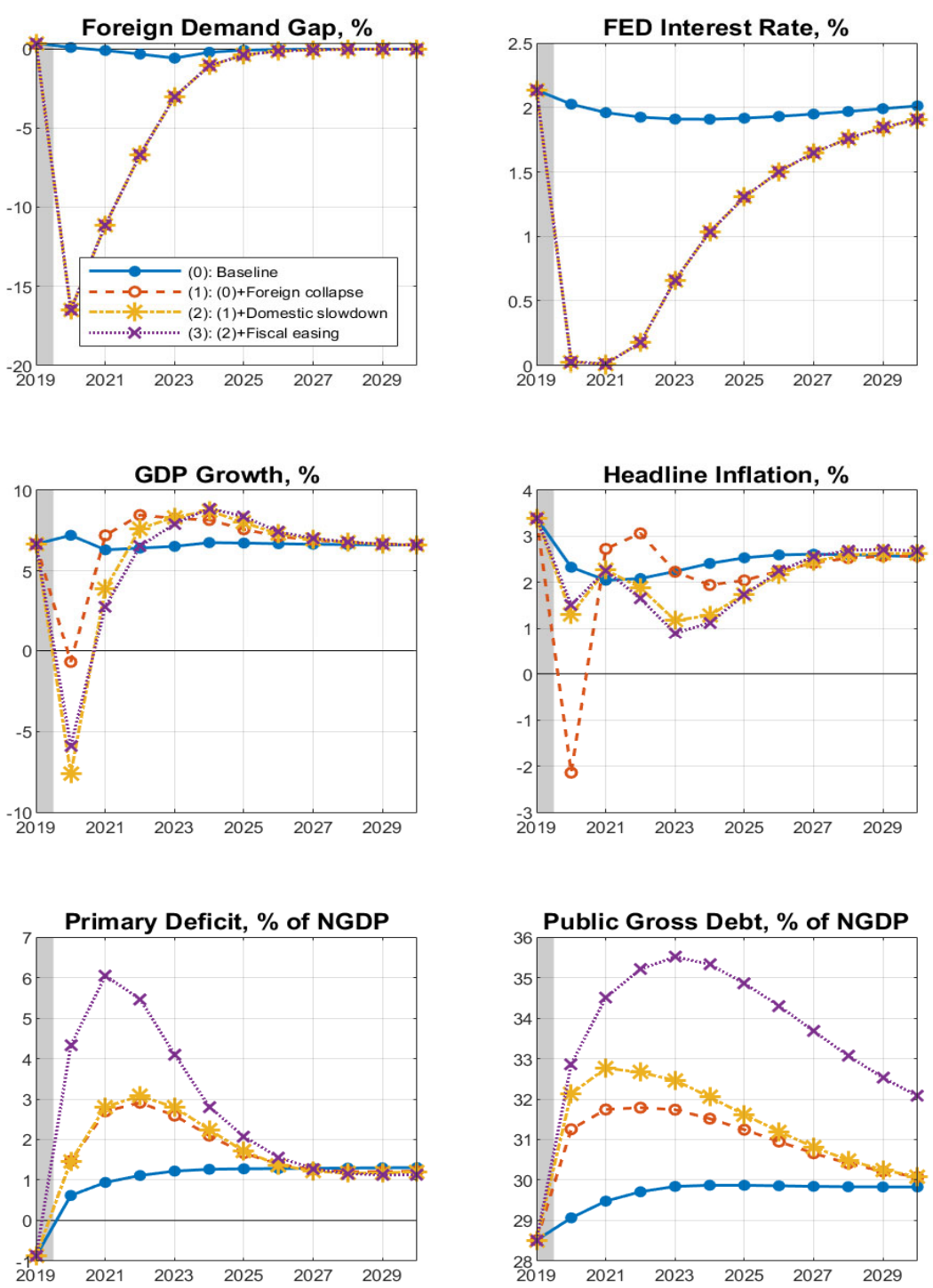

Notes: The blue line (0) denotes the simulation based on initial prepandemic initial conditions. The red (1), yellow (2), and purple (3) lines denotes the layers of assumptions described in the text.

Source: CAMFI, author's simulations.

For the first layer, it is assumed that economic activity declines significantly in France, Germany, the US, and the UK (Figure 10). We also assume that the US Federal Reserve System keeps the policy rate at or near zero in 2020 and 2021 before gradually lifting it toward its neutral level of about 1 percent. Oil prices plunge in 2020 and are assumed to recover only slightly in 2021. The second layer captures a decline in domestic demand driven by the drop in private consumption and investment as domestic agents start to expect a global recession. Analyses of the Cambodia national account data, input-output tables, and the GFC 
experience suggest that domestic demand can drop by cumulative 2 percentage points in $2020-1$ and the country risk premium stay higher by 200 bps in 2020-1 due to tighter global financial conditions for emerging market economies. Food prices increase as pre-crisis food supply channels are interrupted. The initial Covid- 19 shock is, of course, not anticipated by domestic agents.

In the second layer we also make a judgment call about the medium-term supply-side disruptions caused by the pandemic. Tourism travel restrictions extending into 2021, or even 2022, and a sustained decline in demand for Cambodian export goods is likely to slow investment in both physical and human capital. The corresponding slowdown in productivity growth and disruptions in the supply chains would suppress potential GDP growth for some time. Compared to the steady state, we therefore envisage a scenario of cuts of 4.5 in potential GDP growth in 2020 and 3.5 percentage points in 2021, which would fully dissipate only by $2024 .{ }^{16}$ The judgment call was guided by the estimated decline in the natural rate of interest in past pandemics (Jordà and others 2020) and the Penn Wharton model estimates of lasting macroeconomic impacts of the coronavirus on the US (Dinerstein and Huntley 2020) and emerging market economies (S\&P Global Ratings 2020).

The third layer of the Covid-19 scenario captures the impact of a possible discretionary fiscal response. Specifically, our scenario assumes that the public debt target goes up temporarily by 5 percentage points in 2020 and returns only gradually to the original level. In the model the agents fully anticipate the fiscal response: the authorities and private agents share the same information.

\section{B. The Results}

Simulation results from the counterfactual scenario suggest a deep recession in 2020 before a gradual recovery starting in 2021. As shown in the third chart in Figure 10, in the first layer the recession in advanced economies can bring Cambodia's growth down to $-1 \frac{1}{4}$ percent in 2020 compared to the baseline projection of 6 percent. In the second layer, domestic demand slows economic growth to $-81 / 4$ percent. Headline inflation is projected to decline slightly because of slackening in the economy and lower oil prices. These two factors offset the 4percentage point increase in domestic food prices due to the supply channel interruptions and resulting hoarding of food.

In the third layer of the scenario, we expect the fiscal stimulus to boost real growth by about $2 \frac{1}{2}$ percent, bringing GDP growth to $-5^{3 / 4}$ percent. The economy will start recovering in 2021 , growing at almost 3 percent and closing the output gap in 2022. We note that the fiscal stimulus has only a short-lived impact on growth - the scenario assumes only a temporary increase in the debt target, similar to the GFC episode. Needless to say, the temporary nature of the debt target increase is announced, and it remains credible.

\footnotetext{
${ }^{16}$ The simulated slowdown in potential GDP growth by 4.5 percentage points in 2020 implies a rate of growth of potential GDP of only 2.0 percent, since steady-state growth is calibrated at 6.5 percent.
} 
The results of the fiscal stimulus layer should be taken with a grain of salt. The model assumes a fiscal multiplier of $1 / 2$ based on cross-country experience (Appendix B). Should the actual fiscal multiplier be lower, the effect of the fiscal stimulus will be smaller; if the multiplier is higher, the effect will be larger. The case for a smaller fiscal multiplier could be based on the limited effectiveness of spending and lags in budget implementation. The case for a larger multiplier can be supported by the fact that additional public spending targets liquidity-constrained households and that during this crisis import leakages are likely smaller.

\section{Caveats and Potential Extensions}

We have designed and calibrated a simple macrofiscal, semistructural model and applied it to Cambodia, CAMFI. Though this parsimonious model has obvious limitations, many of them can be addressed by extending the model for additional blocks. Because of the structure of Cambodia's economy and data availability problems, we have emphasized the simplicity of the model-realizing that simplicity comes at the cost of there being only a rudimentary supply side and ignoring many stock-and-flow relationships. For example, we capture fiscal accounting, but there is no treatment of the current account or the NBC balance sheet. Possible extensions suitable for more complex economies might be, among others, separation of core and noncore price indexes; breakdown of aggregate demand into an agricultural (commodity) component and a nonagricultural (noncommodity) component; development of the term structure of interest rates; and explicit modeling of external trade. Extensions of the model need to be weighed against data availability and the modeling complexity that extensions may introduce. It is highly important, however, that the model retain its conceptual simplicity and clarity; an overly complex model is unlikely to provide a fast and straightforward discussion of policy-relevant issues.

Some extensions are simple, such as accounting for alternative monetary and exchange rate regimes. There is a library of matching formulations for the monetary policy reaction equation and the equations modeling the exchange rate that correspond to the characteristics of these regimes. We can build on a variety of semistructural monetary models developed in the context of IMF technical assistance: they cover the continuum of cases from free floats and open/closed capital accounts to pegs and closed capital accounts.

Users need to be mindful of the model's predictive ability, since the short series available for Cambodia prevent most attempts at econometric evaluation. Economically reasonable estimates of important parameters tend to cover a wide range, and it is sometimes difficult to decide between competing representations of the economy. Combining the calibration approach with Bayesian estimation, perhaps employing system priors, may help, but it is unlikely to overcome the data deficiencies in most low-income and emerging market countries (Andrle and Benes 2013). ${ }^{17}$ Ultimately, model users must never take too seriously a

\footnotetext{
${ }^{17}$ System priors are priors about the model's features and behavior as a system, such as the maximum duration of the response of debt to a particular shock. System priors would help to parametrize the model when the policymaker has a clear view of the policy horizon, but the model developer has insufficient data to estimate the transmission mechanism.
} 
single parameterization of a particular model. Models help in discussing and assessing risks to the forecast, but they are no substitute for understanding the data and the economy.

Also deserving more attention, perhaps, is the vulnerability of low-income and emergingmarket countries to global financial market shocks to, among other factors, their risk premiums and rollover risk. It would be useful to explore in a more structured way the role of the exchange rate and the interest rate in the aggregate demand, aggregate supply, and debt equations. We know relatively little about the effects of balance sheet mismatches or unsustainable debt on economies like Cambodia's. These extensions will be difficult to apply in the current linear framework; the reaction of financial market and debt developments is known to be nonlinear.

\section{Conclusions}

This paper describes an approach to simulating and forecasting macroeconomic variables using CAMFI, a simple macrofiscal, semistructural model. Unlike traditional IMF detailed financial programming, the results here focus on only a few variables that are consistent with the New Keynesian framework that is the usual practice in modern academic literature, policymaking, and forecasting. We see the approach described here as a complement to FP: the model is much more limited in scope than the coverage of variables that is common in FP. Needless to say, its small size does not necessarily mean that operating such a semistructural model is easy. Model developers and users need to start with a clear understanding of how the data are constructed, collect the key stylized facts, and pay attention to changes in the transmission mechanism as economies evolve.

We have outlined a basic version of the model and calibrated a parsimonious version of it for Cambodia, validating our calibration by using only a few impulse response functions; testing the consistency of unobserved variables against a generally accepted narrative; and assessing the accuracy of our recursive forecasts. We then used the model to simulate the medium-term economic impact of the Covid-19 pandemic. We demonstrated the relative ease and consistency with which a stacked set of assumptions can be developed into a full-blown counterfactual scenario and presented to the policymaker.

We contend that the FP framework can be tailored to virtually any fiscal, monetary, or exchange rate policy regime. However, the startup costs to begin using even a relatively simple model of this type are substantial, and its sustained use requires periodic updates and maintenance. Our hope is that its successful use may spawn a community of practice in support of practical, policy-oriented modeling. Armed with such tools, economists can make useful contributions to policy dialogue and surveillance in IMF member countries. 


\section{REFERENCES}

Alesina, Alberto, and Silvia Ardagna, 2010, "Large Changes in Fiscal Policy: Taxes Versus Spending," Tax Policy and the Economy 24: 35-68.

Andrle, Michal, and Jaromir Benes, 2013, "System Priors: Formulating Priors about DSGE Models' Properties," IMF Working Paper 13/257 (Washington: IMF). Available at: https://www.imf.org/ /media/Websites/IMF/imported-full-textpdf/external/pubs/ft/wp/2013/ wp13257.ashx

Batini Nicoletta, Luc Eyraud, Lorenzo Forni, and Anke Weber, 2014, "Fiscal Multipliers: Size, Determinants, and Use in Macroeconomic Projections," Technical Notes and Manuals (Washington: IMF). Available at: https://www.imf.org/external/pubs/ft/tnm/2014/tnm1404.pdf.

Berg, Andrew, Philip D. Karam, and Douglas Laxton, 2006, “A Practical Model-Based Approach to Monetary Policy Analysis-Overview," IMF Working Paper 06/80 (Washington: IMF). Available at: https://www.imf.org/external/pubs/ft/wp/2006/wp0680.pdf.

BOK Knowledge Partnership Program with Cambodia, 2016, Modeling for Macroeconomic Analysis and Inflation Forecasting (Soul: The Bank of Korea and Yonsei University). Available at: https://www.nbc.org.kh/download files/research papers/english/ NBC_BOK_Modelling_for_Macro_Analysis.pdf.

Bulíř, Aleš, and A. Javier Hamann, 2008, "Volatility of Development Aid: From the Frying Pan into the Fire?" World Development 36: 2048-66.

Bulír, Aleš, and Jan Vlček, forthcoming, "Monetary Transmission: Are Emerging Market and Low-Income Countries Different?" Journal of Policy Modeling. Available at: http://www.cnb.cz/miranda2/export/sites/www.cnb.cz/en/research/research_publicati ons/cnb_wp/download/cnbwp_2016_02.pdf.

De Jong, Piet, 1991, “The Diffuse Kalman Filter.” The Annals of Statistics 19: 1073-83.

Dinerstein, Marcos, and Jon Huntley, 2020, "Lasting Macroeconomic Impacts of the Coronavirus Crisis, Absent Fiscal Policy Response," Penn Wharton Budget Model Blog. Available at: https://budgetmodel.wharton.upenn.edu/issues/ 2020/3/27/ macroeconomic-impacts-coronavirus.

Easterly, William, 2006, "An Identity Crisis? Examining IMF Financial Programming," World Development 34: 964-80.

Engen, Eric, and R. Glenn Hubbard, 2004, "Federal Government Debt and Interest Rates," NBER Working Paper 10681 (Cambridge, MA: National Bureau of Economic Research). Available at: http://www.nber.org/papers/w1068.

Fatás, Antonio, and Ilian Mihov, 2001, "The Effects of Fiscal Policy on Consumption and Employment: Theory and Evidence," CEPR Discussion Papers 2760. (London: Center for Economic and Policy Research). 
Fedelino, Annalisa, Anna Ivanova, and Mark Horton, 2009, "Computing Cyclically Adjusted Balances and Automatic Stabilizers," Technical Notes and Manuals (Washington: IMF). Available at: http://www.imf.org/external/pubs/ft/ tnm/2009/tnm0905.pdf.

Fukac, Martin, and Adrian Pagan, 2010, "Structural Macro-Econometric Modelling in a Policy Environment," Research Working Paper, RWP 10-08 (Kansas City: Federal Reserve Bank of Kansas City). Available at: https://www.kansascityfed.org/ /media/ files/publicat/reswkpap/pdf/rwp10-08.pdf.

Ghosh, Atish, Charis Christofides, Jun Kim, Laura Papi, Uma Ramakrishnan, Alun Thomas, and Juan Zalduendo, 2005, "The Design of IMF-Supported Programs," IMF Occasional Paper 241. (Washington: IMF). Available at: https://www.imf.org/external/pubs/nft/op/241/op241.pdf.

Giavazzi, Francesco, and Marco. Pagano, 1996, "Non-Keynesian Effects of Fiscal Policy Changes: International Evidence and the Swedish Experience," Swedish Economic Policy Review 3: 67-112.

Hamilton, James, 1994, Time Series Analysis, Princeton: Princeton University Press.

HM Treasury, 2008, "Fiscal Policy in the UK" (London: HM Treasury). Retrieved on 12/11/2008. Available at: https://archive.is/20121224030428/http://www.hmtreasury.gov.uk/fiscal policy.htm.

Ilzetzki, Ethan, 2011, "Fiscal Policy and Debt Dynamics in Developing Countries," Policy Research Working Paper Series 5666 (Washington: World Bank). Available at: https://elibrary.worldbank.org/doi/pdf/10.1596/1813-9450-5666.

IMF (International Monetary Fund), 2018a, "Cambodia: Technical Assistance Report-Tax Administration Modernization Priorities 2019-23," IMF Country Report No.18/305 (Washington: IMF). Available at: https://www.imf.org/en/Publications/CR/Issues/2018/11/07/Cambodia-TechnicalAssistance-Report-Tax-Administration-Modernization-Priorities-201923-46336.

, 2018b, "Cambodia: 2018 Article IV Consultation; Press Release; Staff Report" (Washington: IMF). Available at: https://www.imf.org/ /media/Files/Publications/ CR/2018/cr18369.ashx.

- 2018c, Annual Report on Exchange Arrangements and Exchange Restrictions 2018, (Washington: IMF). Available at: https://www.elibraryareaer.imf.org/Documents/YearlyReport/ AREAER 2018.pdf.

, 2019, "Cambodia: 2019 Article IV Consultation; Press Release; Staff Report" (Washington: IMF). Available at: https://www.imf.org/ /media/Files/Publications/ CR/2019/1KHMEA2019001.ashx

Jaramillo, Laura, and Anke Weber, 2012, "Bond Yields in Emerging Economies: It Matters What State You Are In.” IMF Working Paper 12/198 (Washington: IMF). Available at: https://www.imf.org/ /media/Websites/IMF/imported-full-text$\mathrm{pdf} / \mathrm{external} / \mathrm{pubs} / \mathrm{ft} / \mathrm{wp} / 2012 /$ wp12198.ashx.

Jordà, Òscar, Sanjay R. Singh, and Alan M. Taylor, 2020, "Longer-run Economic Consequences of Pandemics,” NBER Working Paper No. 26934 (Cambridge, MA: 
National Bureau of Economic Research). Available at: https://www.nber.org/papers/ w26934.pdf.

Kamenik, Ondra, Zdenek Tuma, David Vavra, and Zuzana Smidova, 2013, "A Simple Fiscal Stress Testing Model: Case Studies of Austrian, Czech and German Economies," OECD Economics Department Working Papers No. 1074 (Paris: OECD). Available at: https://www.oecd-ilibrary.org/a-simple-fiscal-stress-testingmodel $5 \mathrm{k} 43 \mathrm{nxm} 8 \mathrm{hfvf}$.pdf?itemId=\%2Fcontent $\% 2 \mathrm{Fpaper} \% 2 \mathrm{~F} 5 \mathrm{k} 43 \mathrm{nxm} 8 \mathrm{hfvf}$ en\&mimeType $=$ pdf.

Obstfeld, Maurice, Jay C. Shambaugh, and Alan M. Taylor, 2005, "The Trilemma in History: Tradeoffs Among Exchange Rates, Monetary Policies, and Capital Mobility." Review of Economics and Statistics 87: 423-38.

Owyang, Michael, Valerie Ramey, and Sarah Zubairy, 2013, “Are Government Spending Multipliers Greater During Periods of Slack? Evidence from 20th Century Historical Data," American Economic Review: Papers \& Proceedings 103: 129-34.

Pallage, Stéphane, Michel A. Robe, and Catherine Bérubé, 2006, "The Potential of Foreign Aid as Insurance," IMF Staff Papers 53(3): 453-75.

Plödt, Martin, and Claire A. Reicher, 2015, "Estimating Fiscal Policy Reaction Functions: The Role of Model Specification," Journal of Macroeconomics 46: 113-28.

Polak, Jacques J., 1991, “The Changing Nature of IMF Conditionality,” Essays in International Finance, No. 184 (Princeton: Princeton University Press). Available at: https://ies.princeton.edu/pdf/E184.pdf.

, 1997, "The IMF Monetary Model at Forty," IMF Working Paper 49/97 (Washington: IMF). Available at: https://www.imf.org/ /media/Websites/IMF/ imported-full-text-pdf/external/pubs/ft/wp/ wp9749.ashx.

Price, Robert, Thai-Thanh Dang, and Jarmila Botev, 2015, “Adjusting Fiscal Balances for the Business Cycle: New Tax and Expenditure Elasticity Estimates for OECD Countries," OECD Working Paper ECO/WKP 1275 (Paris: OECD). Available at: http://www.oecd.org/officialdocuments/publicdisplaydocumentpdf/?cote=ECO/WKP (2015)93\&docLanguage $=$ En.

Ramey, Valerie A., and Sarah Zubairy, 2018, "Government Spending Multipliers in Good Times and in Bad: Evidence from US Historical Data," Journal of Political Economy 126: 850-901.

Robichek, Walter E., 1967, "Financial Programing Exercises of the International Monetary Fund in Latin America," an address to a seminar of Brazilian professors of economics, Rio de Janeiro, Brazil, September 20, 1967 (Washington: IMF).

Romero-Barrutieta, Alma Lucía, Aleš Bulír, and José Daniel Rodríguez-Delgado, 2015, "The Dynamic Implications of Debt Relief for Low-Income Countries," Review of Development Finance 5: 1-12.

Rungcharoenkitkul, Phurichai, 2012, "Modeling with Limited Data: Estimating Potential Growth in Cambodia," IMF Working Paper 12/96 (Washington: IMF). Available at: 
https://www.imf.org/ /media/Websites/IMF/imported-full-textpdf/external/pubs/ft/wp/2012/ wp1296.ashx.

S\&P Global Ratings, 2020, "Economic Research: COVID-19 Deals A Larger, Longer Hit to Global GDP," Comments published on April 16, 2020. Available at: https://www.spglobal.com/ratings/en/research/articles/200416-economic-researchcovid-19-deals-a-larger-longer-hit-to-global-gdp-11440500.

Schumacher, Malte, and Dawid Żochowski, 2017, "The Risk Premium Channel and Longterm Growth," ECB Working Paper No 2114 (Frankfurt: European Central Bank). Available at: https://www.ecb.europa.eu/pub/pdf/scpwps/ecb.wp2114.en.pdf.

World Economic Forum, 2019, "Global Competitiveness Report.” Available at: http://www3.weforum.org/docs/WEF_TheGlobalCompetitivenessReport2019.pdf. 
APPENDIXES

\section{A. Fiscal Deposits}

Without ready access to international bond markets or opting to issue local bonds, the Cambodian government has been building deposits at the National Bank of Cambodia (NBC) as a buffer (see Figure 1, Chart 6 in the main text). The following identity holds:

\section{Change in fiscal deposits $=$ Overall deficit - Change in gross public debt}

How to model the fiscal deposits? On the one hand, the headline fiscal deficit has been correlated with the business cycle, that is, the output gap. On the other hand, the evolution of gross debt has reflected the 30-percent debt-to-GDP target and fluctuations around that level caused by donor disbursement choices, progress in project execution, and so on. These stylized facts suggest that the cyclical factors drive the gradual accumulation of the fiscal deposits (Chart A1). In the model we therefore calibrate the elasticity of the deposits to the output gap as equal to 0.3 .

Figure A1: Output Gap and Fiscal Deposits, 2002-19

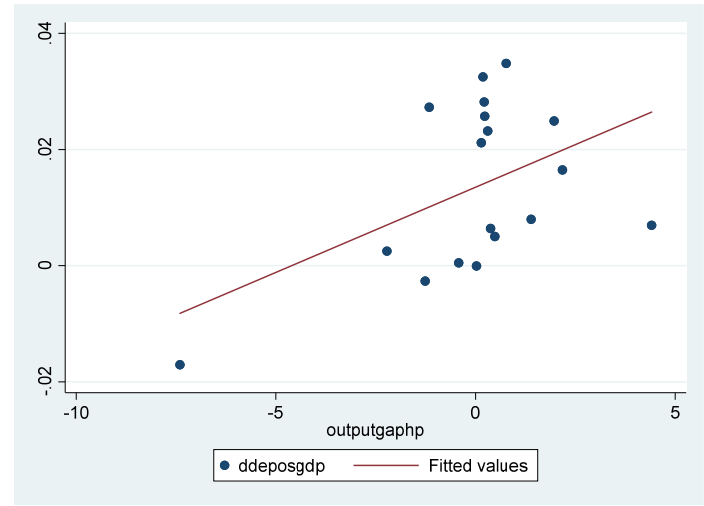

Notes: The figure shows fiscal deposits in percent of GDP on the vertical axis and output gap in percent of trend GDP on the horizontal axis. The fitted values line is the linear trend.

Source: International Monetary Fund (IMF) data and authors' calculations. 


\section{B. The Fiscal Multiplier Estimates for Cambodia}

The fiscal multiplier measures the impact on output of an unexpected, discretionary change in fiscal policy. Empirically, individual-country estimation of fiscal multipliers is fraught with problems (Owyang and others 2013; Ramey and Zubairy 2018) even in countries with long, good-quality time series and it is almost impossible in a country like Cambodia. Batini and others (2014) have suggested instead a "bucket approach" to calibrate the magnitude of the multiplier based on country characteristics.

The empirical literature provides widely varying multiplier estimates: (1) Because it is difficult to identify an unexpected, discretionary change in the fiscal variables, most developments in taxes and spending are instead reactions to the business cycle. (2) The fiscal multipliers, which vary over time and across countries and monetary policy regimes, draw on a range of factors, including the state of the economy, the specific fiscal instrument used, the extent to which fiscal decisions provoke changes in other policies, such as monetary, and the structure of the economy. (3) Because most empirical studies deal with advanced economies, relatively little is known about the size of the multiplier in emerging and low-income countries. One generally accepted finding is that spending multipliers in low-income countries are, on average, lower than in advanced economies (Ilzetzki 2011). Table B1 summarizes some of the offsetting factors.

Table B1. Factors Affecting the Fiscal Multiplier in Low-Income Countries

\begin{tabular}{|l|l|}
\hline Multiplier-increasing factors & Multiplier-decreasing factors \\
\hline - Less developed financial markets & - More open economy (import leakage) \\
- Less forward-looking economic agents & - Larger precautionary saving \\
- Less effective monetary policy response & - Inefficiencies in public spending and \\
- Smaller automatic stabilizers & $\begin{array}{l}\text { revenue administration } \\
\text { - Lower government debt }\end{array}$ \\
& $\begin{array}{l}\text { Long-lasting positive output gaps due to } \\
\text { suply constraints }\end{array}$ \\
\hline
\end{tabular}

We apply the methodology of Batini and others (2014) to calibrate Cambodia's fiscal multiplier in three steps (Table B2):

Step 1: Assign a score to Cambodia based on the number of characteristics associated with large fiscal multipliers: 1 if yes, 0 otherwise.

Step 2: Sum up the scores to determine the likely bucket of the multiplier (low, medium, or high).

Step 3: Adjust the range assigned using the scoring method based on Cambodia's temporary characteristics.

After steps 1 and 2, Cambodia falls into the low-multiplier bucket, suggesting that the fiscal multiplier ranges between 0.1 and 0.3 . Adjusting for temporary factors prevailing in 2020, the estimate of the first-year fiscal multiplier falls in the range of 0.5 to 0.7 . Hence, in the model we calibrate the impact multiplier to be equal to 0.5 . 
Table B2. Cambodia's Fiscal Multiplier in 2020: The Bucket Approach

\section{Step 1: Scoring the Characteristics}

\begin{tabular}{|c|c|c|c|}
\hline Characteristics & Assess & Score & Indicators [benchmark] \\
\hline Low trade openness & No & 0 & $\begin{array}{l}\text { Imports } / \mathrm{GDP}=73 \% \text { (average past } 5 \\
\text { years), }[>40 \%]\end{array}$ \\
\hline High labor market rigidity & No & 0 & $\begin{array}{l}\text { Weak labor unions (World Economic } \\
\text { Forum, 2019) }\end{array}$ \\
\hline Small automatic stabilizers & Yes & 1 & Public spending/GDP $=23 \% ;[<45 \%]$ \\
\hline Fixed exchange rate regime & Yes & 1 & $\begin{array}{l}\text { Stabilized around } 4,050 \text { riels per US } \\
\text { dollar }\end{array}$ \\
\hline Low public debt & Yes & 1 & Debt-to-GDP $=28 \% ;[<40 \%]$ \\
\hline $\begin{array}{l}\text { Effective public expenditure } \\
\text { and revenue management }\end{array}$ & No & 0 & $\begin{array}{l}\text { Based on } 2015 \text { evaluation of Public } \\
\text { Financial Management of Cambodia. }\end{array}$ \\
\hline \multicolumn{4}{|l|}{ Step 2: Total Score and Group } \\
\hline \multirow[t]{2}{*}{ Total score } & $\begin{array}{l}\text { Low } \\
\text { multiplier }\end{array}$ & 3 & $\begin{array}{l}\text { Low multiplier, if the total score is less } \\
\text { than } 3 \text {. }\end{array}$ \\
\hline & $\begin{array}{l}\text { Fiscal } \\
\text { multiplier }\end{array}$ & $0.1-0.3$ & Low multiplier: between 0.1 and 0.3 \\
\hline \multicolumn{4}{|c|}{ Step 3: Adjustment for Temporary Factors } \\
\hline $\begin{array}{l}\text { Composition of the fiscal } \\
\text { stimulus }\end{array}$ & & 0.25 & $\begin{array}{l}\text { The fiscal stimulus involves both } \\
\text { spending and net taxes (increase the } \\
\text { lower bound by } 0.5 \text { and then divide by } \\
\text { 2) }\end{array}$ \\
\hline Economic cycle & & 0.17 & $\begin{array}{l}\text { Negative output gap due to the } \\
\text { Covid-19 pandemic (adjustment, } \\
0.5^{*} 1 / 3 \text { ) }\end{array}$ \\
\hline Monetary policy & & 0.05 & $\begin{array}{l}\text { Constrained by high dollarization } \\
(0.1 * 1 / 2)\end{array}$ \\
\hline $\begin{array}{l}\text { The multiplier after } \\
\text { adjustment }\end{array}$ & & $0.5-0.7$ & $\begin{array}{l}\text { The upper and lower ranges are adjusted } \\
\text { by the following additive factors: }+0.25 \\
\text { (two-thirds of the adjustment relates to } \\
\text { expenditures), }+0.17 \text { (large negative } \\
\text { output gap), and }+0.05 \text { (constrained } \\
\text { monetary policy). }\end{array}$ \\
\hline
\end{tabular}

Source: Authors' calculation based on Batini and others (2014). 


\section{The CAMFI Model Codes}

All Matlab model codes and the corresponding version of the IRIS toolbox are available at: https://imfbox.box.com/s/9txhtrg77m37f4asf6tvo9cnuq4j9hh9.

The key model equations are as follows:

Aggregate demand (Dynamic IS curve):

$$
\hat{y}_{t}=a_{1} \hat{y}_{t-1}+a_{2} E_{t} \hat{y}_{t+1}-a_{3} m c i_{t}+a_{4} f_{t}^{i m p}+a_{5} \hat{y}_{t}^{*}+\varepsilon_{t}^{y} \text {, }
$$

The monetary conditions index:

$$
m c i_{t}=a_{6}\left(\hat{r}_{t}+c r_{-} \text {prem }_{t}\right)+\left(1-a_{6}\right)\left(-\hat{z}_{t}\right) \text {, }
$$

Aggregate supply (the New-Keynesian Phillips curve):

$$
\pi_{t}=b_{1} \pi_{t-1}+\left(1-b_{1}\right) E_{t} \pi_{t+1}+b_{2} r m c_{t}+b_{3} \Delta o i l_{t}+\varepsilon_{t}^{\pi}
$$

Real marginal cost:

$$
r m c_{t}=b_{4} \hat{y}_{t}+\left(1-b_{4}\right) \hat{z}_{t}
$$

The uncovered interest rate parity (UIP) condition:

$$
i_{t}=\left(E_{t} s_{t+1}-s_{t}\right)+i_{t}^{*}+\text { prem }_{t}
$$

The nominal exchange rate:

$$
\Delta s_{t}=c_{1} \Delta s_{t-1}+\left(1-c_{1}\right)\left(\Delta \tilde{s}_{t}-c_{2} s_{t-1}\right)+\varepsilon_{t}^{S}
$$

The fiscal impulse:

$$
f_{t}^{i m p}=\left(\operatorname{cad}_{t}-\operatorname{cad}_{t-1}\right)+f_{4} \varepsilon_{t}^{b^{t a r}} \pm f_{5} \varepsilon_{t}^{b}
$$

The fiscal reaction function:

$$
\operatorname{cad}_{t}=f_{7}\left(\operatorname{cad}_{t-1}-f_{10} \hat{y}_{t}\right)+\left(1-f_{7}\right)\left(\operatorname{cad}_{t}^{t a r}-f_{8} b_{t}^{d e v}\right)+\varepsilon_{t}^{c d}
$$

The cyclically-adjusted primary deficit:

$$
\operatorname{cad}_{t}=p d_{t}+f_{3} \hat{y}_{t}
$$

The total deficit:

$$
d_{t}=p d_{t}+i d_{t}
$$


Expected debt deviation path:

$$
b_{t}^{d e v}=f_{9}\left(b_{t}-b_{t}^{\text {tar }}\right)+\left(1-f_{9}\right) E_{t} b_{t+1}^{\text {dev }}
$$

Gross debt accumulation:

$$
b_{t}=d_{t}+\Delta x_{t}+\left(1+\Delta s_{t}\right) b_{t-1} /\left(1+g_{t}\right)
$$

Fiscal deposit accumulation:

$$
x_{t}=\Delta x_{t}+\left(1+\Delta s_{t}\right) x_{t-1} /\left(1+g_{t}\right)
$$

The fiscal deposit reaction function:

$$
\Delta x_{t}=g_{2} \Delta x_{t-1}+\left(1-g_{2}\right)\left(\Delta \tilde{x}_{t}+g_{3} \hat{y}_{t}+g_{4}\left(p d_{t}-p d_{t}^{\text {tar }}\right)\right)+\varepsilon_{t}^{x}
$$

Debt service:

$$
i d_{t}=i_{t-1}^{G o v}\left(1+\Delta s_{t}\right) b_{t-1} /\left(1+g_{t}\right)
$$

Purchasing power parity (PPP) condition:

$$
z_{t}=s_{t}+p_{t}^{*}-p_{t}
$$

The real interest rate trend:

$$
\tilde{r}_{t}=h_{5} \tilde{r}_{t-1}+\left(1-h_{5}\right)\left(\Delta \tilde{z}_{t+1}+\tilde{r}_{t}^{*}+\text { prem }_{t}\right)
$$

The country risk premium:

$$
\text { prem }_{t}=h_{6} \text { prem }_{t-1}+\left(1-h_{6}\right)\left(\text { prem }+h_{12}\left(b_{t}-\bar{b}-\left(x_{t}-\bar{x}\right)\right)\right)+\varepsilon_{t}^{\text {prem }}
$$

The equilibrium real exchange rate trend:

$$
\Delta \tilde{z}_{t}=h_{7} \Delta \tilde{z}_{t-1}+\left(1-h_{7}\right) \Delta \bar{z}+\varepsilon_{t}^{\Delta z}
$$

Potential output growth:

$$
\Delta \tilde{y}_{t}=h_{8} \Delta \tilde{y}_{t-1}+\left(1-h_{8}\right)\left(\Delta \bar{y}-h_{13}\left(\tilde{r}_{t}-\bar{r}\right)\right)+\varepsilon_{t}^{\Delta y} \text {. }
$$

